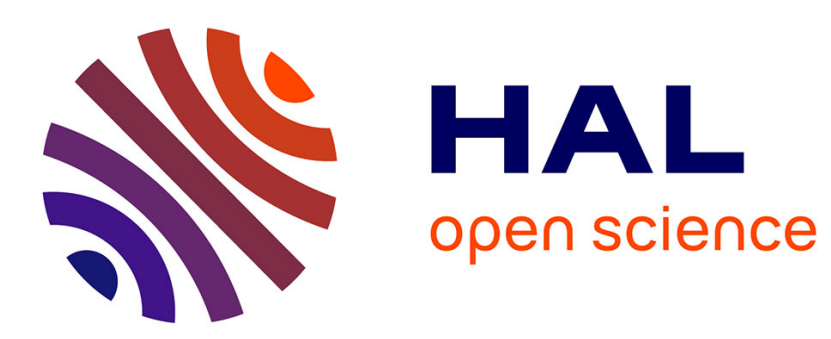

\title{
Rapid Metabolization of Protectin D1 by $\beta$-Oxidation of Its Polar Head Chain
}

Laurence Balas, Patrizia Risé, Dayaker Gandrath, Gianenrico Rovati, Chiara Bolego, Fabio Stellari, Annalisa Trenti, Carola Buccellati, Thierry Durand, Angelo Sala

\section{To cite this version:}

Laurence Balas, Patrizia Risé, Dayaker Gandrath, Gianenrico Rovati, Chiara Bolego, et al.. Rapid Metabolization of Protectin D1 by $\beta$-Oxidation of Its Polar Head Chain. Journal of Medicinal Chemistry, 2019, 62 (21), pp.9961-9975. 10.1021/acs.jmedchem.9b01463 . hal-02387872

\section{HAL Id: hal-02387872 \\ https://hal.science/hal-02387872}

Submitted on 20 Dec 2019

HAL is a multi-disciplinary open access archive for the deposit and dissemination of scientific research documents, whether they are published or not. The documents may come from teaching and research institutions in France or abroad, or from public or private research centers.
L'archive ouverte pluridisciplinaire HAL, est destinée au dépôt et à la diffusion de documents scientifiques de niveau recherche, publiés ou non, émanant des établissements d'enseignement et de recherche français ou étrangers, des laboratoires publics ou privés. 


\title{
Rapid Metabolization of Protectin D1 by $\beta$-Oxidation of Its Polar Head Chain
}

Laurence Balas*a, Patrizia Riséb, Dayaker Gandrath ${ }^{\mathrm{a}}$, Gianenrico Rovati ${ }^{\mathrm{b}}$, Chiara Bolego ${ }^{\mathrm{c}}$, Fabio Stellarid, Annalisa Trentie, Carola Buccellatib ${ }^{\mathrm{b}}$, Thierry Durand ${ }^{\mathrm{a}}$, and Angelo Sala*b,f

a Institut des Biomolécules Max Mousseron (IBMM), UMR 5247, CNRS, Université Montpellier, ENSCM, Montpellier, France.

b Dipartimento di Scienze Farmaceutiche, Università degli Studi di Milano, Via Balzaretti 9, 20133 Milano, Italia

c Dipartimento di Scienze del Farmaco, Università di Padova, Largo Meneghetti 2, 35131 Padova, Italia. ${ }^{d}$ Chiesi Farmaceutici, Via Paradigna, 43122 Parma, Italia.

e Dipartimento di Medicina, Università di Padova, Padova, Via Giustiniani 2, 35131 Padova, Italia, f IBIM, Consiglio Nazionale delle Ricerche, Via Ugo la Malfa 153, 90146 Palermo, Italia.

\begin{abstract}
Protectin D1 (NPD1, PD1) has been proposed to play a key role in the resolution of inflammation. Aside from its $\omega$-monohydroxylated metabolite, little has been reported on its metabolic fate. Upon NPD1 incubation in HepG2 cells, LC-MS/MS revealed the formation of two main metabolites, identified as 2,3dinor-NPD1 and 2,3,4,5-tetranor-NPD1 by comparison with standards obtained through demanding total chemical syntheses. These data represent the first evidence of $\beta$-oxidation occurring in specialized proresolving mediators (SPMs), and show that the biotransformation of NPD1 by human hepatoma cells is extremely rapid and faster than leukotriene $\left(\mathrm{LTE}_{4}\right)$. Alike $\mathrm{LTE}_{4}$, the main metabolic process occurs from the polar head chain of NPD1. It may limit NPD1 systemic circulation and prevent its urinary excretion, making difficult its detection and quantitation in vivo. Interestingly, tetranor-NPD1, but not dinor-NPD1, maintained the bioactivity of the parent NPD1, inhibiting neutrophil chemotaxis in vitro, and neutrophil tissue infiltration in vivo.
\end{abstract}




\section{INTRODUCTION}

The neuroprotectin D1 (NPD1) is an omega-3 lipid mediator arising from the docosahexaenoic acid (DHA, C22:6 n-3) by the action of lipoxygenase-like and other enzymatic activities either by transcellular metabolism $^{1}$ or in a single cell type ${ }^{2}$. This endogenous dihydroxylated and non-cyclic metabolite was shown to possess anti-inflammatory activities, reducing neutrophil infiltration and accumulation. It participates to the active process of the resolution of inflammation, including wound healing. $\quad 1,3,4$ The various biological properties of NPD1, its biosynthesis, involvement in many inflammatory and/or infectious diseases in cultured models, rodents and human, have been summarized in many recent reviews and article. ${ }^{5-9}$

The emerging role of NPD1 as a critical mediator of the resolution phase of inflammation ${ }^{8,10}$ is making the assessment of its plasmatic concentrations as a potential index of in vivo formation a very important issue. The literature reflects the extreme difficulty in quantifying Specialized Pro-resolving Mediators (SPMs), in human fluids, mainly the protectin class of compounds that includes NPD1. Several teams provided evidence of the endogenous production of NPD1, both in healthy volunteers ${ }^{11,12}$ and patients with peripheral artery disease ${ }^{13}$, metabolic syndrome ${ }^{14}$, chronic kidney disease ${ }^{15}$ or tuberculosis ${ }^{16}$. However, the reported circulating quantities in blood ${ }^{12-14,16-18}$ (serum, plasma) or urines ${ }^{19}$ are extremely low (much lower than for the other SPM), with levels that often do not exceed the limit of quantification (LOQ) even in cases of severe inflammation or high dose omega-3 supplementation. ${ }^{11,14,15,17,20-22}$ Given the surprising discrepancy between the low blood levels measured, the high biological efficacy and relevance attributed to NPD1, it might be possible that the NPD1 plasmatic concentrations may not be predictive of the actual production in vivo.

Apart from the fact that NPD1 (as most of the SPMs) requires demanding and careful handling as it is prone to isomerize to its E,E,E-isomer (poor chemical stability with light, air, acid pH), NPD1 may be quickly removed from its bioactive site by rapid local and systemic (hepatic) biotransformation. 
Beside the previously reported $\omega$-oxidation generating a biologically active omega-hydroxylated derivative (22-OH-NPD1) ${ }^{1,23}$ in human leukocyte, little is known about NPD1 metabolic fate.

Scheme 1 outlines the different putative metabolic pathways for NPD1. According to the major known pathways of dihydroxylated eicosanoid metabolites, ${ }^{24-26}$ the previously reported 22-OH-NPD1 may be oxidized to the corresponding dicarboxylic acid 22-COOH-NPD1, prior to further prospective $\beta$ oxidation of the tail chain. Omega-1 hydroxylation reaction (observed in some resolvins ${ }^{27}$ ) seems more unlikely as it should provide an isobaric isomer of 22-OH-NPD1, which should have been detected along with 22-OH-NPD1 if present, unless it is rapidly oxidized to the corresponding ketones. Oxidation of one of the allylic alcohols may also take place as observed in resolvin 18-oxo-RvE2 3 , maresin 14-oxo-MaR $1^{29}$ and lipoxin 15-oxo-LXA $4{ }^{30}$ for instance. Alternatively, the polar head chain of NPD1 may be shortened by two carbon atoms, resulting in a $\mathrm{C} 20$ carbon derivative 7, without loss of the central E,E,Z-triene unit flanked on both sides by the two hydroxyl groups. Subsequently, the $\beta$-oxidation process may go on, starting from the resulting dinor-NPD1 7. As a result, NPD1 may be shortened by four carbon atoms, leading to the tetranor-NPD1 8. 




NPD1 may likely undergo hepatic biotransformation by $\beta$-oxidation (scheme 1) since its C1-C6 carbon fragment is identical (scheme 2) to the C13-C18 fragment of 18-COOH-19,20-dinor-LTE ${ }_{4} 1$ and of 18COOH-19,20-dinor-LTB ${ }_{4}$ 2, which are converted to 16-COOH-14,15-dihydro-17,18,19,20-tetranor-LTE $\mathbf{3}^{31-33}$, and 16-COOH-14,15-dihydro-17,18,19,20-tetranor-LTB ${ }_{4} \mathbf{4}^{24}$ respectively. More recently, and highly relevant with respect to NPD1, Lawson et al. ${ }^{34}$ also showed that the neuroprostane $7-\mathrm{F}_{4 \mathrm{t}} \mathrm{-NeuroP}$ 5, which shares the same polar head C1-C6 fragment as NPD1, could not be detected in human urine because of its rapid biotransformation into the isoprostane $5-\mathrm{F}_{3 \mathrm{t}}$-IsoP 6 by $\beta$-oxidation (Scheme 2 ). 
Scheme 2. Biotransformation of lipids showing a similar $\gamma$-unsaturated carboxylated chain

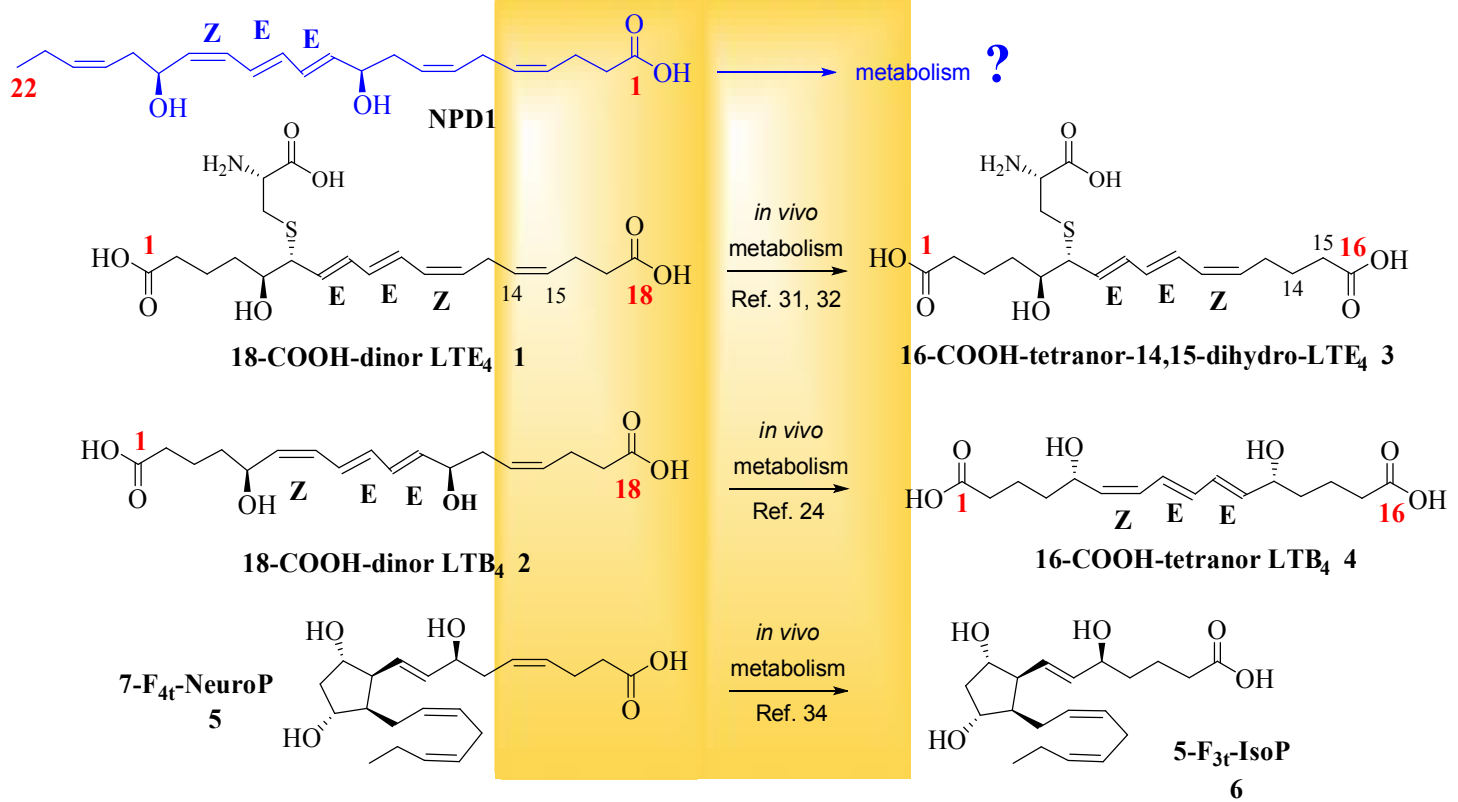

To address the gaps of knowledge in protectin metabolism, we herein investigated NPD1 biotransformation in human HepG2 cells, as a model of potential hepatic metabolism in man. To confirm the identification of the major novel NPD1 metabolites we developed their total synthesis. We established a quantitative LC-MS/MS method to profile NPD1 and its main $\beta$-oxidized derivatives, studied the timecourse formation of these novel metabolites in HepG2 hepatoma cells in the presence of different concentrations of the parent NPD1 compound, compared it to LTE ${ }_{4}$ metabolism and analyzed human urines from healthy subjects for their presence. Biological activity of the novel metabolites of NPD1 was also evaluated in vitro and confirmed in vivo.

\section{RESULTS AND DISCUSSION}

We investigated NPD1 metabolism process upon incubation of known quantities of synthetic NPD1 in cultured cells. 


\section{Identification of NPD1 metabolites in HepG2 cells}

The analysis of cell media after 4 hours of incubation with human hepatoma cell lines (HepG2), was carried out by RP-HPLC coupled to negative ions electrospray MS in a linear ion trap LC/MS, collecting full scan mass spectra, alignment and subtraction of extracted, single m/z chromatograms from HepG2 media obtained either in the presence or in the absence of $13 \mu \mathrm{M}$ NPD1, Along with some remaining NPD1 (at m/z 359), three main peaks were observed at the $\mathrm{m} / \mathrm{z} 305, \mathrm{~m} / \mathrm{z} 333$ and $\mathrm{m} / \mathrm{z} 375$ (Figure 1) consistent with the molecular weight of the carboxylate anion of tetranor-NPD1 8, dinor-NPD1 7 (scheme 1) and 22-OH-NPD1, respectively.

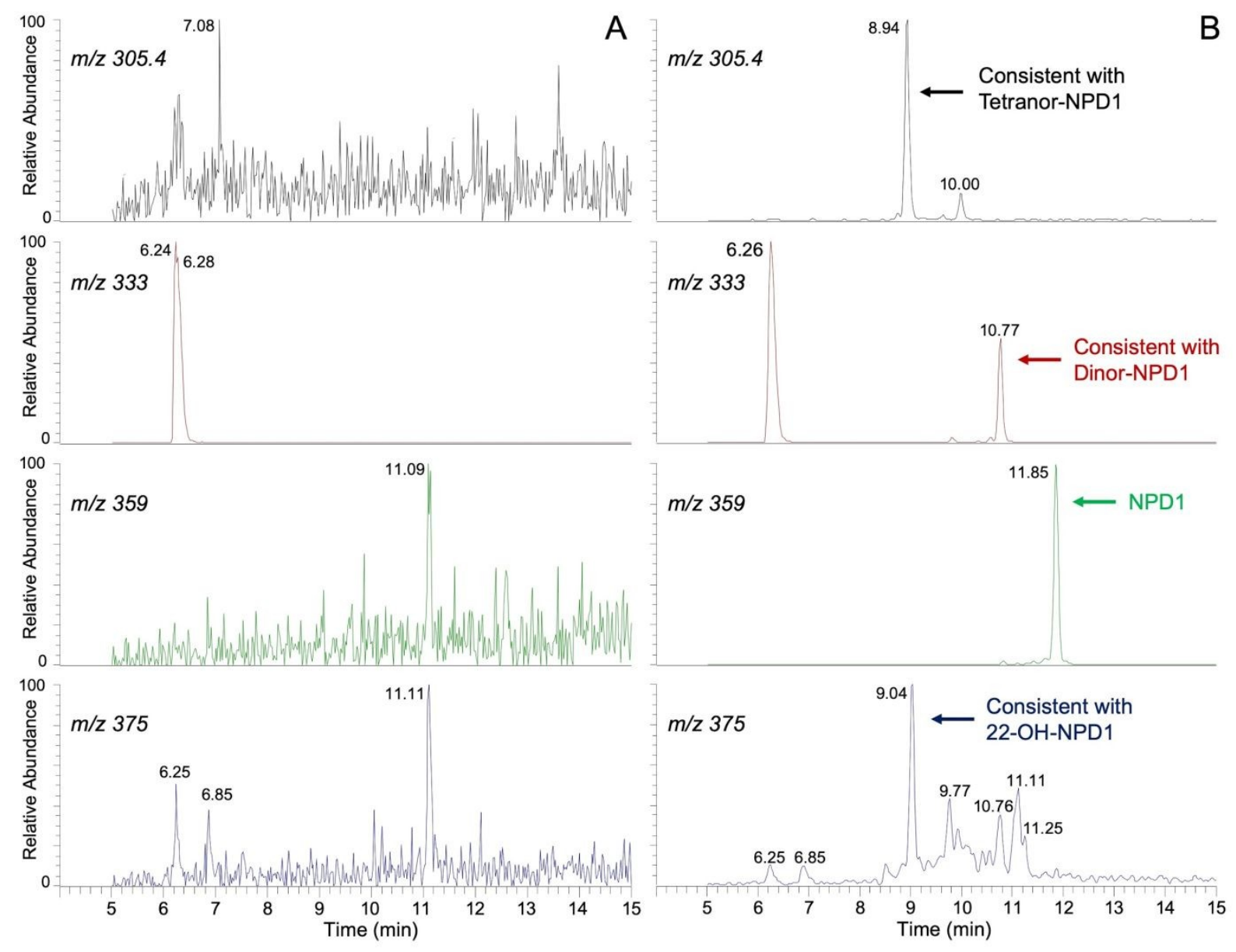

Figure 1. Analysis of the HepG2 cell medium by RP-HPLC/MS using a linear ion trap mass spectrometer with electrospray source. HepG2 cells were incubated for 4 hours without (panel A) or with $13 \mu \mathrm{M}$ NPD1 (panel B); cell media were extracted and analyzed by RP-HPLC coupled to a linear ion trap mass spectrometer equipped with electrospray ion source. Full scans $(\mathrm{m} / \mathrm{z} 100-1000)$ were 
collected and single ion chromatograms extracted, over-imposed and used to locate peaks associated with NPD1 incubation. Significant peaks present in NPD1 incubates only are marked with an arrow.

Tandem mass spectrometric analysis of the abovementioned metabolites generated spectra identical to those of tetranor-NPD1 (Figure 2A), dinor-NPD1 (Figure 2B), and NPD1 (data not shown) synthetic standards (see chemical synthesis below), confirming that NPD1 can indeed undergo several rounds of $\beta$ oxidation in a model of human liver cells. MS/MS analysis of the ion at m/z 375, generated a spectrum with major fragment ions at m/z 295, 261, 217 and 153, in line with the fragmentation previously reported ${ }^{23}$ for 22-OH-NPD1 (see supporting information file, figure S1).

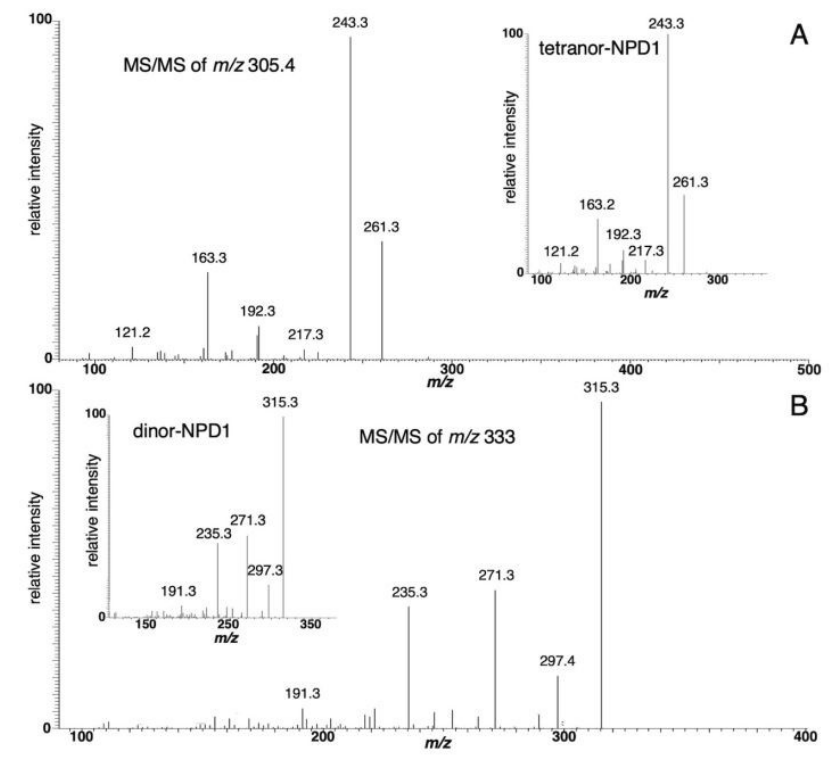

Figure 2. MS/MS analysis of NPD1 metabolites in HepG2 cell medium. The MS/MS spectra of compounds found in HepG2 cell medium after 4 hours of incubation with $13 \mu \mathrm{M}$ of NPD1 were collected by fragmentation of molecular ions at m/z 305.4 (panel A) and m/z 333 (panel B). MS/MS spectra of synthetic tetranor-NPD1 and dinor-NPD1 are shown in insets.

These two novel metabolites of NPD1 (compounds 7 and 8) represent the first evidence of $\beta$ oxidation occurring in SPMs: while potential $\beta$-oxidation following $\omega$-oxidation was clearly a concern 
in the development of analogs of lipoxins $3^{35}$, leading to the development of aspirin-triggered lipoxin analogs protected at the omega end, no identification of $\beta$-oxidized metabolites was reported to date at either the tail chain or the polar head chain. In the present in vitro study, only traces of 22-OH-NPD1 were detected in HepG2 cells, and no peak could be assigned to the corresponding omega-carboxylated derivative (22-COOH-NPD1), suggesting that, contrary to eicosanoids ( $\mathrm{LTB}_{4}, \mathrm{LTE}_{4}, \mathrm{LXB}_{4}$ for instance), the metabolization of the tail chain of NPD1 is not the main metabolic pathway of NPD1. In our hands, selected ion monitoring for targeting the expected $\mathrm{m} / \mathrm{z}$ for putative ketone formation (scheme1) did not allow detection of any oxo-protectin derivatives.

\section{Chemical synthesis of NPD1 and its dinor and tetranor metabolites (7 and 8)}

NPD1 was synthesized at a ten milligram scale in order to add it at several concentrations in cultured cells and monitor its presence or disappearance upon several incubation periods. Since LC-MS/MS analysis of incubated cell media suggested (see above) the formation of 1,2-dinor 7 and 1,2,3,4 tetranor 8 derivatives (which, herein, will be called dinor-NPD1 and tetranor-NPD1 for better convenience), we envisioned their total synthesis. These two targets served as chemical tools for comparison and full elucidation of the structure of the newly observed metabolite peaks in human hepatocyte models. They were also used for the calibration curves required for quantitation in the time-course experiments (see below).

Based on our flexible strategy reported ${ }^{36}$ in 2014, the three targets NPD1, its dinor 7 and tetranor 8 may be obtained using two Wittig olefination reactions via an advanced pivotal intermediate 9. This ynediene 9 is a diastereomer of an ynediene that was previousl $y^{36}$ prepared via Sonogashira cross-coupling reaction, Colvin and Bestmann-Ohira alkynylation reactions. Thus, in the synthesis of the iododiene 10, the (S)butane-triol was simply replaced by its (R)-enantiomer, which can be prepared from (R)-malic acid, much cheaper. The terminal alkyne $\mathbf{1 1}$ may be synthesized from (S)-butane-triol via a Bestmann-Ohira 
alkynylation reaction and suitable protection-deprotection sequence. The retrosynthetic analysis is depicted in scheme 3.

Scheme 3. Retrosynthetic analysis for NPD1 and its $\beta$-oxidized metabolites 7 and 8.

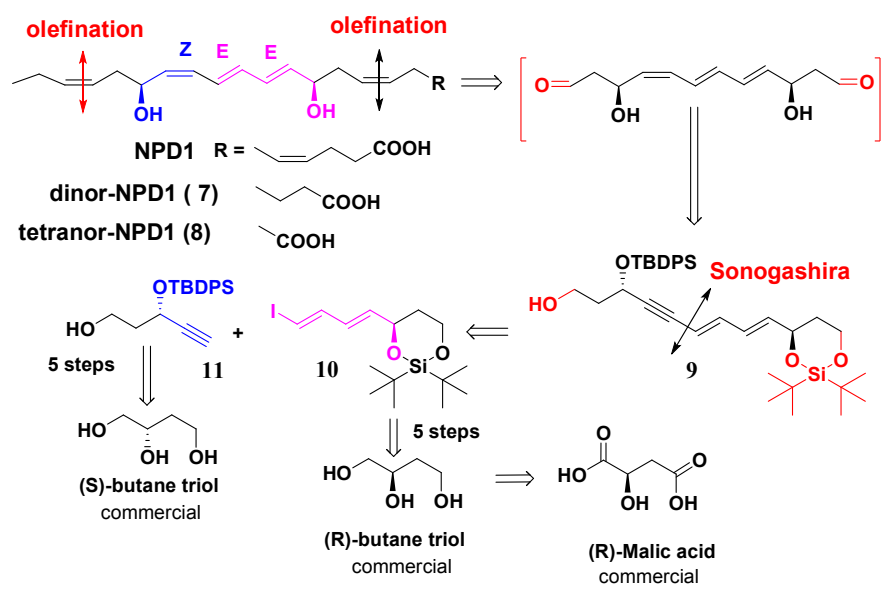

The total synthesis of NPD1 and its dinor 7 and tetranor $\mathbf{8}$ is illustrated in scheme 4 .

The alcohol 9 was oxidized to aldehyde $\mathbf{1 2}$ and subsequently converted to aldehyde 13 (previously reported $^{36}$ with a different configuration for the synthesis of AT-NPD1). 


\section{Scheme 4. Total synthesis of NPD1 and its metabolites 7 and 8.}
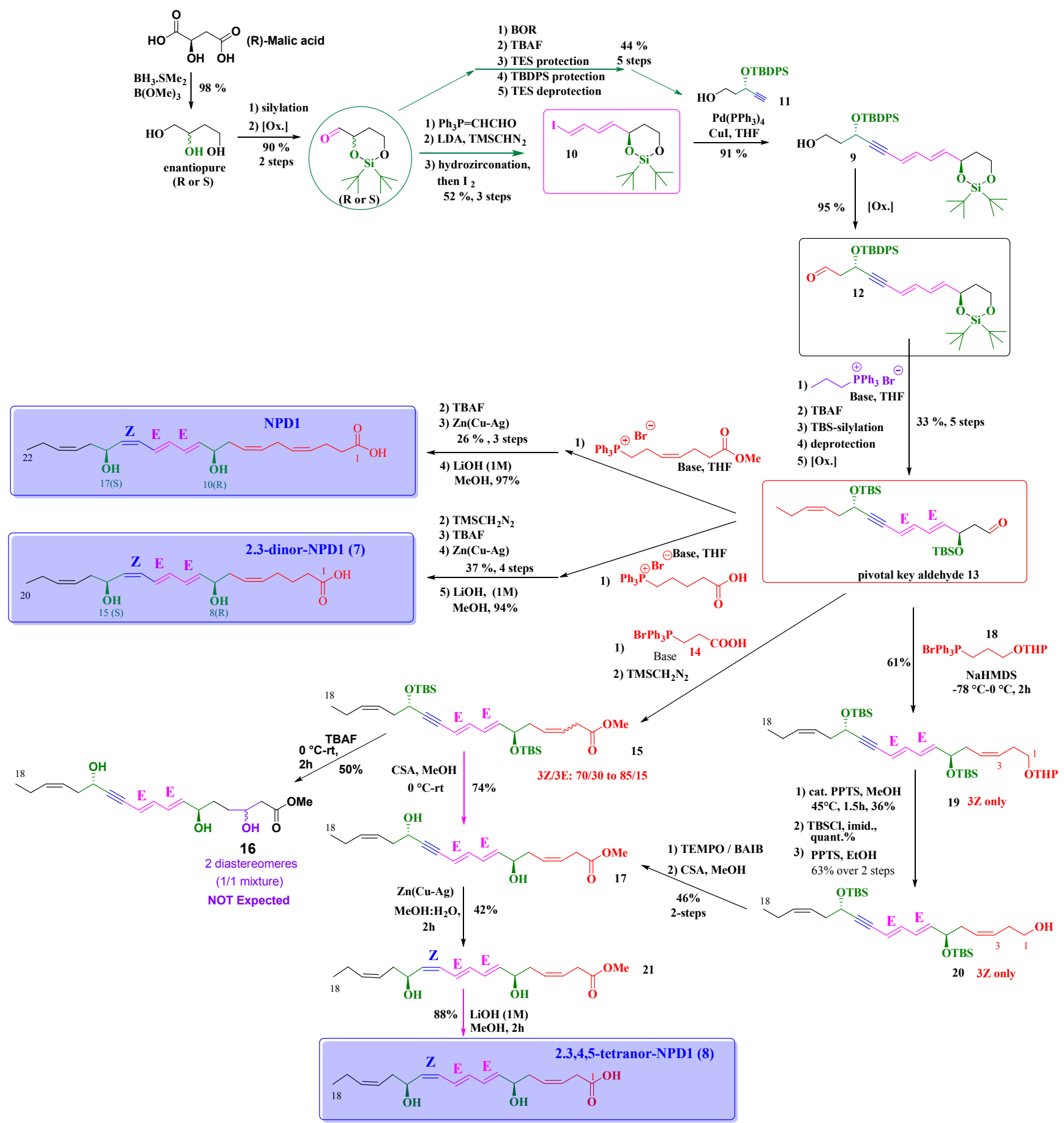

Then, using the same pivotal late advanced key aldehyde 13, the total synthesis of NPD1 and its dinorNPD1 metabolite 7 was achieved in a total of 27 and 22 steps in $2.84 \%$ and $3.92 \%$ overall yield with a longest linear sequence respectively. Compared to our previously reported synthesis of the key aldehyde 
intermediate $\mathbf{1 3}^{36}$ yields were slightly improved. Replacement of a TBS group by a TBDPS group facilitated some selective deprotection steps before the Sonogashira reaction leading to ynediene 9.

The synthesis of NPD1-tetranor 8 (scheme 4) was performed using the same strategy as for NPD1 and dinor-NPD1 7. However, the shortening of the polar head made it more difficult to obtain, due to the activated allylic methylene in the alpha-position to the carboxylated function.

The Wittig reaction between the pivotal aldehyde 13 with the (2-carboxyethyl)triphenylphosphonium bromide $14^{37}$ in the presence of NaHMDS followed by treatment with TMSCHN ${ }_{2}$ afforded the desired Wittig product 15 in 69\% yield. However, contrary to our previous Wittig reactions with this aldehyde 13, the olefination reaction was not stereoselective, leading to a non-separable Z/E mixture (ratio: 70/30 (NaHMDS as base, $-78^{\circ} \mathrm{C}$ to $0^{\circ} \mathrm{C}, 69 \%$ ) to $82 / 18$ (n-BuLi, THF:DMSO, $-5^{\circ} \mathrm{C}, 71 \%$ ). Colder temperatures affected the yields without significantly improving the $\mathrm{Z} / \mathrm{E}$-stereoselectivity $\left(-15^{\circ} \mathrm{C}, \mathrm{Z} / \mathrm{E}: 85 / 15,55 \%\right.$ yield).

Surprisingly, silyl deprotection of ynediene 15 using fluoride anions led to triol 16 instead of the desired diol 17, suggesting an unexpected addition of a hydroxyl group on the isolated Z-double bond. Mild acidic conditions (CSA in $\left.\mathrm{MeOH}, 0^{\circ} \mathrm{C}\right)$ provided the diol 17 (74\%).

To overcome the lack of stereoselectivity with the carboxylated phosphonium 14, the carboxylic function was created after the Wittig reaction. Thus, using the THP-protected phosphonium salt 18, aldehyde 13 was converted to the olefin 19 with an excellent Z-selectivity.

Removal of the THP-group was not selective, providing the expected homoallylic alcohol $\mathbf{2 0}$ in poor yield (36\%) along with partial or full TBS-deprotection. The resulting diol and triol mixture were fully reprotected in the presence of $\mathrm{TBSCl}$ and imidazole prior to the selective deprotection of the primary silyl ether (63\% yield over two steps). Conversion of the resulting primary alcohol 20 to aldehyde and carboxylic acid was more difficult than expected. The Dess-Martin reaction and the Pinnick oxidation failed, leading to degradation products only. Oxidation with PDC in DMF afforded the desired 
carboxylic function in poor yield (20\% yield), albeit complete conversion of alcohol $\mathbf{2 0}$. BAIB/TEMPO oxidation $^{38}$ fully converted the alcohol $\mathbf{2 0}$ to its corresponding carboxylic acid. However tentative purification by flash chromatography over deactivated silica gel led to polar degradation products. Esterification with TMS-diazomethane was then conducted on the crude product to afford the desired ester 17 in $46 \%$ yield over two steps. As for the carboxylic acid, poor stability is observed.

Subsequently, chemo-selective reduction of the triple bond using Spur protocole ${ }^{39}$ provided the expected E,E,Z-conjugated triene 21 in modest yield (42\%). Unfortunately, the compound partially decomposed during the reaction. This unexpected reactivity/stability compared to our previous experience with such reaction $^{36,40}$ is probably due to the highly activated methylene of the polar chain head. Ester hydrolysis with lithium hydroxide yielded the targeted NPD1-tetranor acid 8 in good yield (88\%).

Thus, the total synthesis of the tetranor-NPD1 metabolite 8 was achieved in a total of 21 steps and $2.5 \%$ overall yield with a longest linear sequence.

\section{Quantitative determination of NPD1, dinor-NPD1 (7), and tetranor-NPD1 (8)}

The availability of these synthetic standards allowed confirmation of the newly observed metabolites 7 and $\mathbf{8}$ in HepG2 cells, and the development of a sensitive quantitation method based on RP-HPLC separation coupled to selected reaction monitoring in a triple quadrupole mass spectrometer (Figure S2), using $\boldsymbol{d}_{4}-\mathbf{L T B}_{4}$, a tetradeuterated arachidonic acid derivative sharing essential structural features (i.e. a E,E,Z-conjugated triene flanked by two hydroxyls groups) with NPD1 and its $\beta$-oxidized metabolites, as internal standard (calibration curves, supporting information file, Figure S3).

Time-course incubation of high concentrations of NPD1 $(13 \mu \mathrm{M})$ showed the presence of significant amounts of $\beta$-oxidized metabolites of NPD1 already after 30 minutes of cell incubation with NPD1, with the amount of the parent compound progressively decreasing and reaching near zero after $24 \mathrm{~h}$ of 
incubation (Figure 3A). Dinor-NPD1 7 relative amount increased up to 8h, but also sharply decreased at 24h, while tetranor-NPD1 represented the main metabolite remaining at 24h. The tetranor-NPD1 steadily increased up to 24h, a time point at which it represented almost 9\% of NPD1 measured at time zero (Figure 3B).
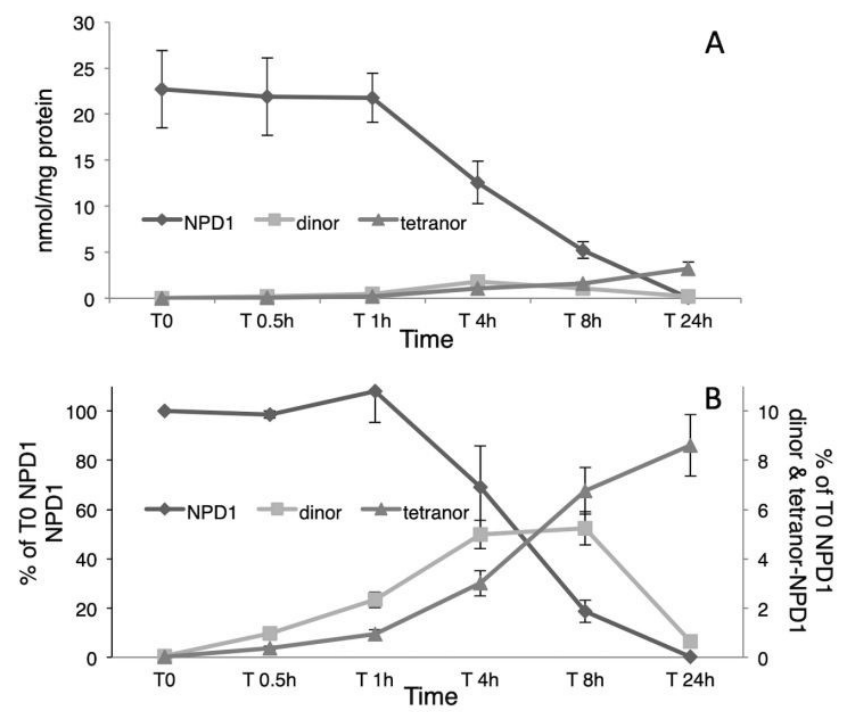

Figure 3. Time-course of NPD1, dinor-NPD1 and tetranor-NPD1, after incubation of HepG2 cells with $13 \mu \mathrm{M}$ NPD1. The medium of HepG2 cells was collected after different incubation times and aliquots were quantitatively analyzed by LC-MS/MS. Panel A: nmoles of NPD1 and its metabolites normalized per mg proteins. Panel B: NPD1, dinor-NPD1 and tetranor-NPD1 nmoles amounts expressed as relative percentage of the amount of NPD1 at T0. Left Y-axis: NPD1 and Right Y-axis: dinor-NPD1 (7) and tetranor-NPD1 (8).

As expected based on the incubations with NPD1, the incubation of HepG2 cells with $13 \mu \mathrm{M}$ of dinorNPD1 (7), also led to the formation of tetranor-NPD1 8 (Figure 4), confirming a second round of $\beta$ oxidation from dinor-NPD1 7. The amount of dinor-NPD1 expressed in nmoles/mg protein rapidly decreased, and at $24 \mathrm{~h}$ less than $0.1 \%$ was present in the incubation medium. Tetranor-NPD1 steadily 
increased reaching a maximum at $8 \mathrm{~h}$, but the amounts detected actually declined at $24 \mathrm{~h}$ (Figure 4), suggesting that further metabolic conversion may be taking place.
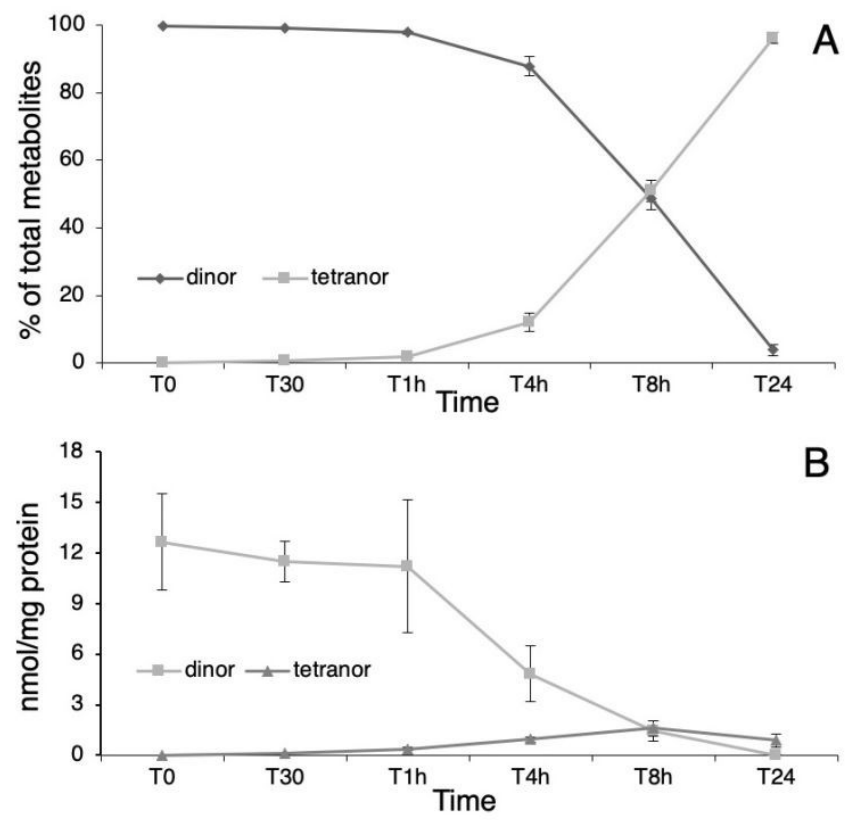

Figure 4. Time-course formation of tetranor-NPD1 upon incubation of HepG2 cells with dinor-

NPD1. The medium of HepG2 cells was collected after different incubation times and aliquots were quantitatively analyzed by LC-MS/MS. Panel A: compounds are expressed as relative percentage, the sum (nmoles) of the 2 compounds as 100. Panel B: nmoles of dinor-NPD1 and tetranor-NPD1 normalized per mg proteins.

NPD1 has been characterized as a potent autocrine and paracrine anti-inflammatory and cytoprotective agent, active at nanomolar and subnanomolar concentration?s ${ }^{41,42}$, possibly throught ${ }^{43}$ the $\mathrm{G}$ proteincoupled receptor GPR37. Like other autacoids NPD1 is synthesized at the site of action typically by transcellular ${ }^{44}$ metabolism. High circulating concentrations of intact NPD1, such as the one used in our above-mentioned in vitro experiments $(13 \mu \mathrm{M})$ are therefore highly unlikely, and liver uptake may therefore result in very low concentrations of NPD1 in hepatic cells. 
Taking advantage of the sensitivity of the LC-MS/MS method set up for the quantitation of NPD1 and its $\beta$-oxidized metabolites, we evaluated the metabolism by HepG2 cells using initial lower concentrations of NPD1.Thus, the use of $2.6 \mu \mathrm{M}$ and $0.52 \mu \mathrm{M}$ of NPD1 (instead of $13 \mu \mathrm{M}$ ), resulted in a much faster metabolism (Figures 5), with NPD1 rapidly disappearing from incubates (Figure 5D). More than 50\% of NPD1 was metabolized within the first 30 minutes of incubation with $0.52 \mu \mathrm{M}$ of NPD1. These results are pointing out the saturation of the enzymes involved in the $\beta$-oxidation of NPD1 occurring at micromolar concentrations of the substrate. Indeed, the estimated half-life of NPD1 in cultured HepG2 cells decreased from over $4 \mathrm{~h}$ at $13 \mu \mathrm{M}$, to $1 \mathrm{~h}$ at $2.6 \mu \mathrm{M}$ and $\approx 30 \mathrm{~min}$ at $0.52 \mu \mathrm{M}$.
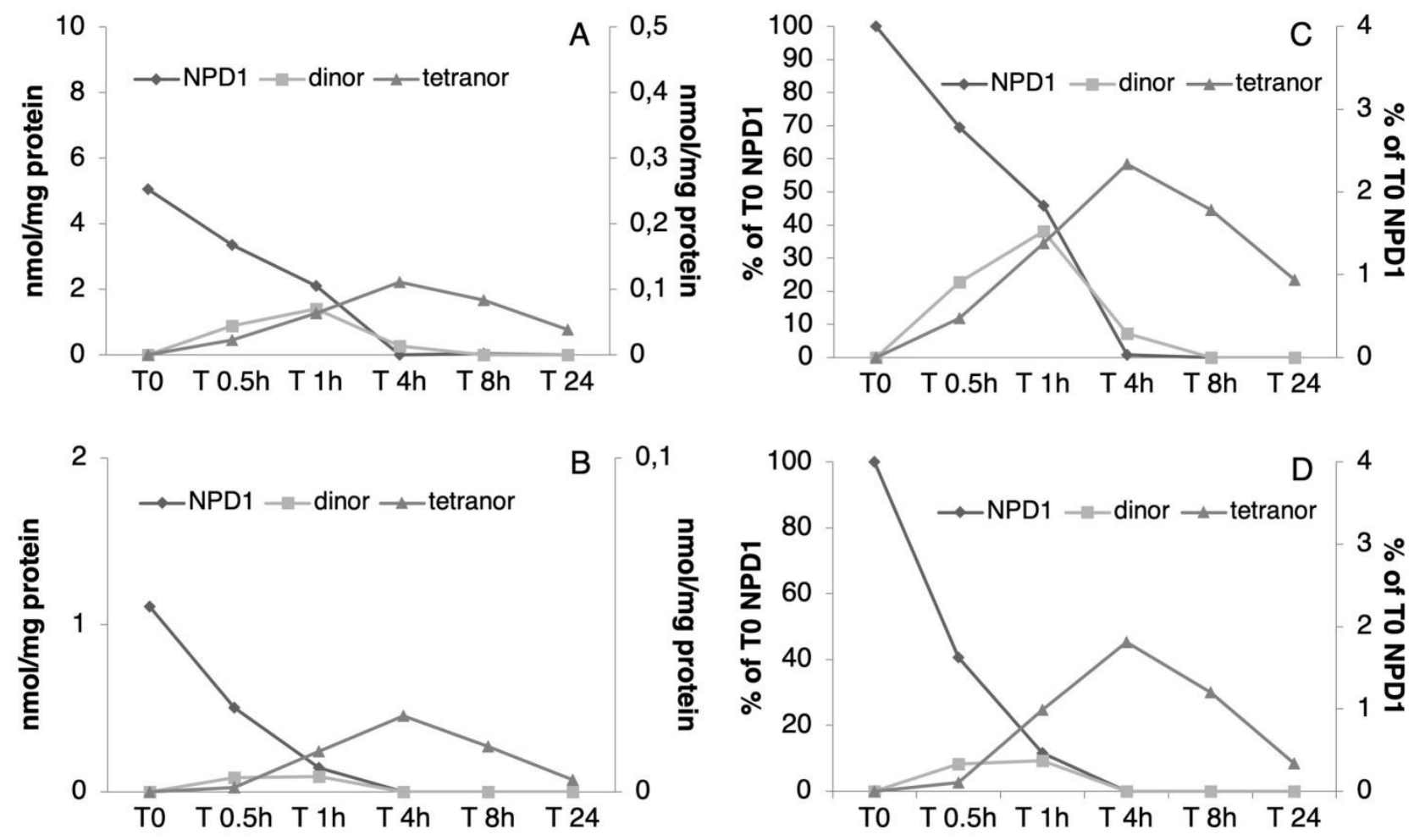

Figure 5. Time-course of NPD1, dinor-NPD1 and tetranor-NPD1, after incubation of HepG2 cells with 2.6 $\mu$ M NPD1 (Panels A and C) and 0.52 $\mu$ M NPD1 (Panels B and D). The medium of HepG2 cells was collected after different incubation times and aliquots were quantitatively analyzed by LCMS/MS. Panel A and B: nmoles of NPD1 and its metabolites normalized per mg proteins. Panel C and D: NPD1, dinor-NPD1 and tetranor-NPD1 nmoles amounts expressed as relative percentage of the amount of NPD1 at T0. Left Y-axis: NPD1; Right Y-axis: dinor-NPD1 and tetranor-NPD1. 
Concomitantly, the concentration of tetranor-NPD1 8 reached a maximum after $4 \mathrm{~h}$ at $2.6 \mu \mathrm{M}$ and 0.52 $\mu \mathrm{M}$ (after $8 \mathrm{~h}$ at $13 \mu \mathrm{M}$ NPD1). Subsequently, especially at submicromolar concentrations of NPD1, the amounts of tetranor-NPD1 sharply declined at longer observation times (Figures 5), indicating that the biotransformation of NPD1 may proceeds beyond the formation of this tetranor metabolite $\mathbf{8}$.

In support to this assertion, minor amounts of other metabolites were also observed in addition to the two main metabolites 7 and $\mathbf{8}$ reported above. Based on RP-HPLC retention time and molecular ions (at $\mathrm{m} / \mathrm{z}$ 279 and m/z 349, Figure 6), they were tentatively identified as hexanor-NPD1 and omega-hydroxylated dinor-NPD1. Although their stereochemistry and configurations cannot be ascertained and although detected in minute quantities only, their presence suggests both a third round of $\beta$-oxidation of the polar head of the native NPD1 together with simultaneousw-hydroxylation of the tail chain of the newly formed metabolites.

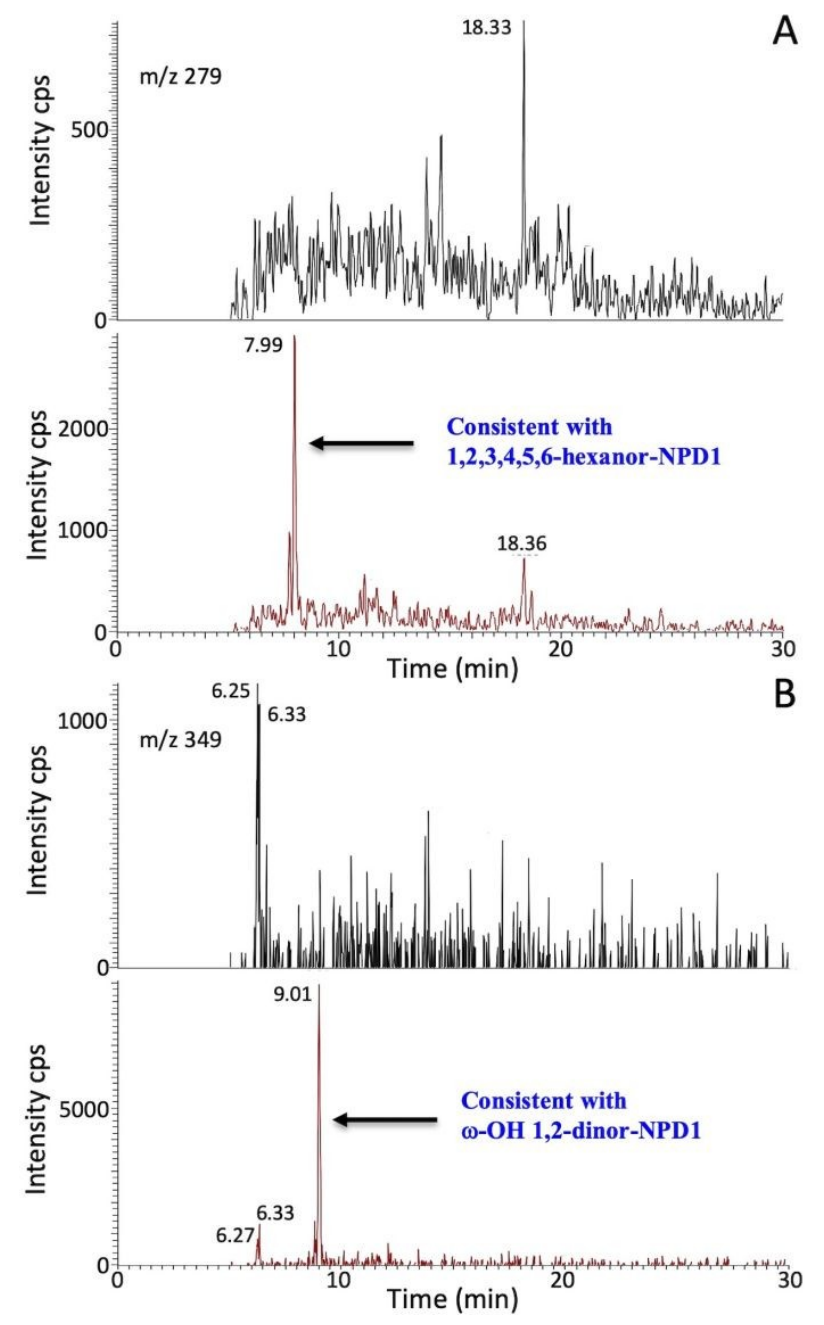


Figure 6. Analysis of the HepG2 cell medium by RP-HPLC/MS using a linear ion trap mass spectrometer with electrospray ionization.HepG2 cells were incubated for 4 hours without (panel A and B, upper tracing) or with $13 \mu \mathrm{M}$ NPD1 (panel A and B, lower tracing); cell media were extracted and analyzed by RP-HPLC coupled to a linear ion trap mass spectrometer equipped with electrospray ion source. Full scans (m/z 100-1000) were collected and single ion chromatograms extracted, over-imposed and used to locate peaks associated with NPD1 incubation. Significant peaks present in NPD1 incubates only are marked with an arrow.

NPD1 is a fatty acid derivative. Its liver $\beta$-oxidation could take place in peroxisomes and/or mitochondria, due to the metabolic interplay $y^{45}$ between these organelles; although the $\beta$-oxidation system in these compartments is chemically very similar, the reactions are catalyzed by different enzymes (encoded by different genes), often being the rate-limiting step of the process. Also, cofactors (NAD $\mathrm{FAD}^{+}, \mathrm{CoASH}$, etc), membrane transporters/channels (ABC transporters, CPTI proteins, etc.), and auxiliary enzymes are involved in the complex regulation of $\beta$-oxidation and lipid metabolism in peroxisomes and mitochondria, ${ }^{46,47}$ and may affect the rate of this metabolic reaction. The rapid formation of dinor-NPD1 provides another example of the involvement of the 2,4-dienoyl-CoA reductase in the processing of the CoA ester of a polyunsaturated fatty acid-derivative, as previously reported for the formation of 16COOH-14,15-dihydro-17,18,19,20-tetranor-LTE 4 3,31, 32, 48, 49 16-COOH-14,15-dihydro-17,18,19,20tetranor-LTB $4^{24}$ and isoprostane $5-\mathrm{F}_{3 \mathrm{t}}$-IsoP $\mathbf{6}^{34}$; the suggested mechanism depicted in scheme 1 is identical to that observed in the metabolism of polyunsaturated fatty acids containing the nearest double bond an even number of carbon atoms from the acyl-CoA ester. ${ }^{50}$ 


\section{Comparison of NPD1 and $\mathrm{LTE}_{4}$ metabolism by HepG2 cells}

Since no example of $\beta$-oxidation has been reported to date in the SPM class of lipid compounds, we compared the efficiency and rate of biotransformation of NPD1 by HepG2 cells with another lipoxygenase-derived polyunsaturated lipid mediator known to undergo $\beta$-oxidation in vivo.

Thus, we compared the disappearance rate of NPD1 with that of leukotriene E4 (LTD) which metabolism was found to exclusively occur from the $\omega$-end of the tail chain only. (A direct $\beta$-oxidation process from the existing carboxylic acid at $\mathrm{C} 1$ in leukotrienes and lipoxines is blocked $\quad{ }^{33}$ by the hydroxyl group at position C5).

Interestingly, under the same conditions of incubations as used for NPD1, Figures 7A and 7B showed that $\mathbf{L T E}_{4}$ remained basically unmetabolized up to $4 \mathrm{~h}$ after the beginning of the incubation at both concentrations tested, highlighting a definitely faster biotransformation of NPD1 by human hepatoma cells. It is important to note that, prior to the $\beta$-oxidation process which shorten the tail chain, $\mathbf{L} \mathbf{T E}_{\mathbf{4}}$ must firstly be $\omega$-oxidized to the corresponding $20-\mathrm{COOH}-\mathrm{LTE}_{4}$ via $\omega$-hydroxylation, a two-step passage that may represent the rate-limiting step of its conversion. Thus, NPD1 metabolism may also be faster than $\mathbf{L T E}_{\mathbf{4}}$ in vivo.
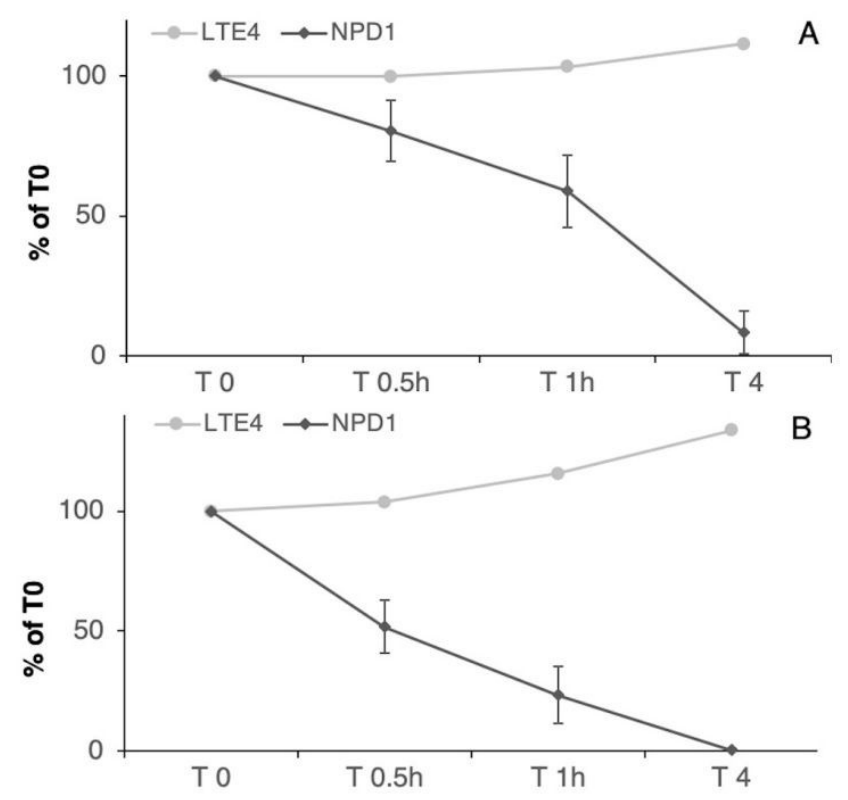
Figure 7. Time-course of NPD1 and $\mathrm{LTE}_{4}$, after incubation of HepG2 cells with $2.6 \mu \mathrm{M}$ (Panels A) or $0.52 \mu \mathrm{M}$ (Panels B). The medium of HepG2 cells was collected after different incubation times and aliquots were quantitatively analyzed by LC-MS/MS. NPD1, and LTE ${ }_{4}$ nmoles amounts expressed as percentage of the amount of NPD1 or $\mathbf{L T E}_{4}$ (respectively) at T0.

\section{Analysis of NPD1 and its metabolites in human urines}

In vivo production of eicosanoids has long been assessed through the determination of local or hepatic metabolites excreted in urines. ${ }^{51-53}$ In touch with a potentially slower systemic biotransformation, LTE ${ }_{4}$ can be found unmodified in healthy human urines and its urinary concentrations are significantly increased in the presence of liver disease. ${ }^{54}$.

Unlike $\mathbf{L T E}_{4}$, we could not detect NPD1 in urines from healthy volunteers although synthetic NPD1 added to urine samples remained intact up to $24 \mathrm{~h}$ at room temperature and was quantitatively recovered, in either the presence or absence of the antioxidant $(105.8 \pm 8.9 \%$, mean $\pm \mathrm{SD}$ in the absence of $\mathrm{BHT})$. Similarly, Lawson et al. reported that 7-F $\mathrm{F}_{4 \mathrm{t}}-\mathrm{NeuroP}$ 5, which shares the same $\gamma$-unsaturated polar head C1C6 fragment as NPD1 (scheme 2), could not be detected in human urine too because of its rapid biotransformation into $5-\mathrm{F}_{3 \mathrm{t}}$-IsoP 6 by $\beta$-oxidation. ${ }^{34}$

Likewise, its novel $\beta$-oxidized metabolites $\mathbf{7}$ and $\mathbf{8}$ could not be positively identified in any of the samples tested. The failure in detecting the corresponding tetranor metabolite of NPD1 in human urines may reflect that additional biotransformations may take place, as suggested by Figure 5, where at sub-micromolar concentrations of NPD1, after reaching a maximal concentration, the amounts of tetranor-NPD1 8 declined in HepG2 and nearly fully disappeared at the longest observation time point.

Besides, we also looked for evidence of $\omega$-oxidation of NPD1, as observed for LTE, in HepG2 incubation media, but only minor amounts of 22-OH-NPD1 could be observed, 
Autacoids such as eicosanoids and SPMs are characterized by potent activities requiring only minute amounts being produced locally and rapidly inactivated both locally and, possibly, systemically. The lack of urinary excretion of intact NPD1, together with the rapid $\beta$-oxidation in HepG2 cells suggests that NPD1, in addition to local biotransformation may undergo a relevant hepatic first-pass effect, accounting for significant variability in plasmatic determinations of NPD1.

\section{Biological activity of newly uncovered $\beta$-oxidized metabolites of NPD1}

As previously reported, ${ }^{23}$ NPD1 dose dependently inhibited LTB 4 -induced chemotaxis of human neutrophils (Figure 8A), a biological activity that is maintained ${ }^{23}$ in the omega-hydroxylated metabolite. Interestingly, the tetranor-NPD1 (8) retained the ability of NPD1 to inhibit $\mathrm{LTB}_{4}$-induced chemotaxis in human PMNL while dinor-NPD1 (7) was ineffective (Figures 8C and 8B, respectively).

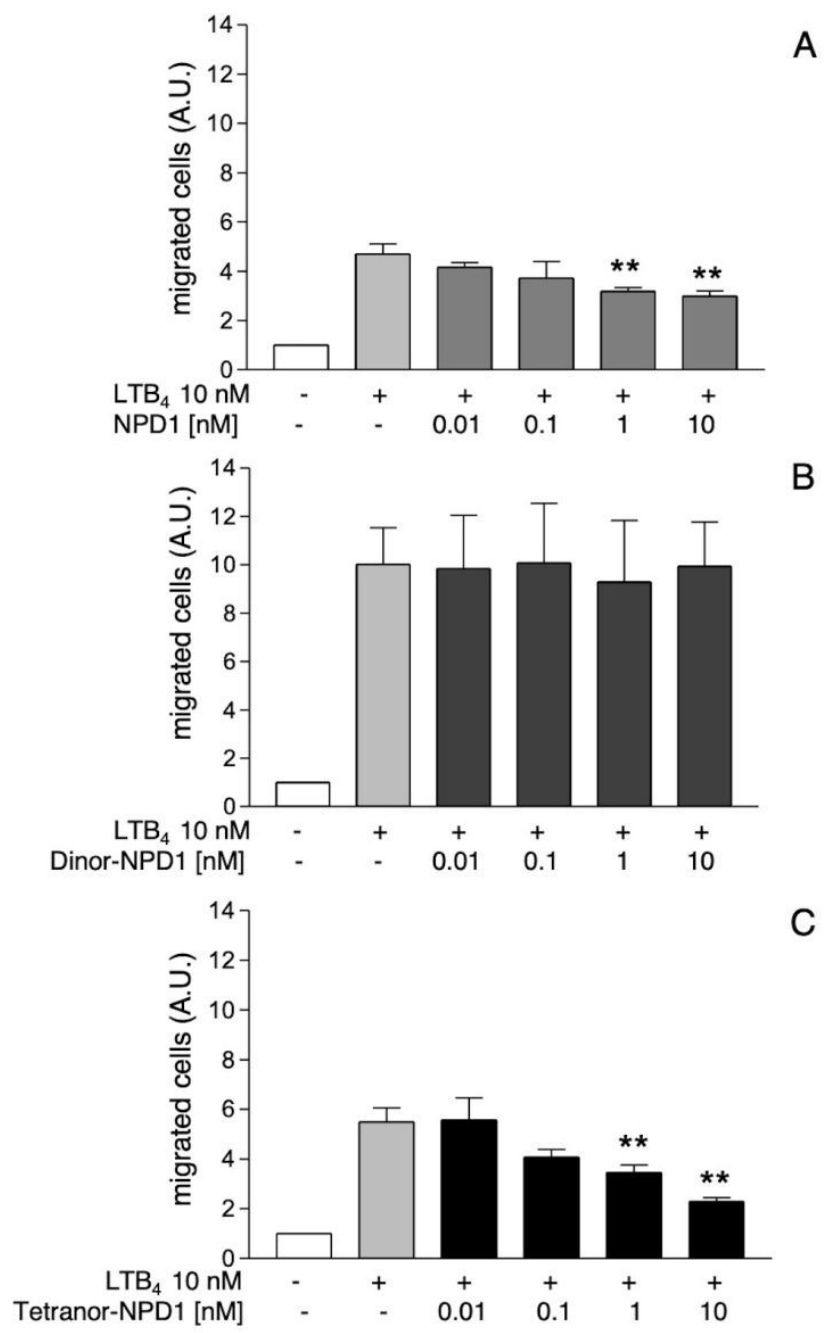


Figure 8. Effect of NPD1 (Panel A), dinor-NPD1 (Panel B) and tetranor NPD1 (Panel C) on LTB ${ }_{4}^{-}$ induced chemotaxis. Human PMNL chemotaxis was assessed in a 48-well modified micro chemotaxis chamber, as described in Methods. Lower chamber contained $\mathrm{LTB}_{4}(10 \mathrm{nM})$ and different concentrations of NPD1 and its $\beta$-oxidized metabolites or their solvent $(\mathrm{EtOH})$; after 90 min at $37^{\circ} \mathrm{C}$, migrated cells were stained and densitometric analysis performed. Data are normalized to negative controls. Original values obtained in sextuplicate are expressed as mean \pm SEM of 3-4 independent assays. Statistical analysis was carried out with one way ANOVA, followed by Dunnet multiple comparison test. **p<0.01 vs LTB 4 alone.

Tetranor-NPD1 (8) bioactivity was also assessed in an in vivo model of acute pulmonary inflammation in mice. Tetranor-NPD1 at the dose of $10 \mathrm{ng} / \mathrm{mouse}$ administered intra-tracheally at the same time as LPS decreased by $20 \%$ the number of infiltrating neutrophils at $24 \mathrm{~h}$ (Figure 9).

These results are pointing to a critical role of the core structure of NPD1 (represented by the conjugated E,E,Z-triene flanked by the two hydroxyl groups) for biological activity while the lack of activity by dinor-NPD1 may involve a critical distance of the carboxyl group.

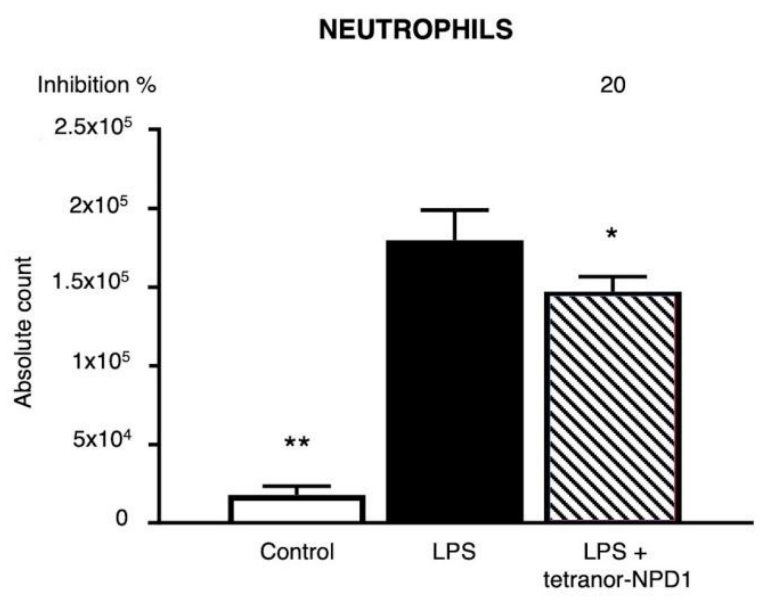

Figure 9. Neutrophils in BAL from lungs of LPS-challenged mice: effect of tetranor-NPD1. Cells recovered from bronchoalveolar lavage (BAL) fluids of control mice and mice challenged with LPS i.t. in the presence or absence of tetranor-NPD1 (10 ng/mouse) were stained for FACS analysis as described 
in Methods. Total granulocytes were gated as CD45 F4/80 and neutrophil population as Ly6 $\mathrm{C}^{\mathrm{hi}} \mathrm{CD} 11 \mathrm{~b}^{\mathrm{hi}}$. True count ${ }^{\circledR}$ tubes were used to determine the absolute number of neutrophils. $\left(^{*}\right) \mathrm{p}<0.05 ;\left(^{* *}\right) \mathrm{p}<0.01$ vs LPS. Each value represents the mean $\pm \operatorname{SEM}(n=3)$.

\section{CONCLUSION}

Time-course incubation of NPD1 in HepG2 cells, a model of human hepatocytes, showed (Figures 3, 4 and 5) the sequential appearance of two novel metabolites of NPD1 with a concomitant, rapid decrease in NPD1 concentrations. A stereoselective synthesis of the two putative main metabolites of NPD1 has been achieved. The strategy (about 22 to 25 steps) features Wittig olefinations, alkyne preparation, hydrometalation, Sonogashira cross coupling reactions while the desired configurations of the two hydroxyl groups, on both sides of the conjugated E,E,Z-triene, are introduced thanks to commercially available enantiopure (S)-1,2,4-butanetriol and (R)-malic acid as chiral pools (scheme 4).

LC-MS/MS data of these synthetic samples matched (Figure 2) data obtained upon incubation of HepG2 cells with NPD1 or dinor-NPD1 7, providing unequivocal evidence that NPD1 can be rapidly metabolized via subsequent rounds of $\beta$-oxidation to newly reported hepatic metabolites dinor-NPD1 7 and tetranor-NPD1 8. $\beta$-oxidation did not require the initial $\omega$-oxidation to the corresponding dicarboxylated metabolite, as previously observed for $\mathbf{L T E}{ }_{4}$ or $\mathbf{L T B} \mathbf{T}_{4}$, but proceeded directly from the polar head of NPD1. These novel metabolites of NPD1 represent the first evidence of $\beta$-oxidation occurring in SPMs.

The formation of the omega oxidized product 22-OH-NPD1 was also observed in trace amounts in HepG2 cells but the corresponding 22-COOH-NPD1 and oxo-derivatives could not be detected.

We also observed additional metabolites that may contribute to the final disappearance of NPD1 from HepG2 incubations; in particular the presence of a putative hexanor-NPD1 suggests that $\beta$-oxidation of NPD1 may proceed beyond the tetranor-metabolite (8) positively identified, and lead to smaller 
fragments contributing to decreasing concentrations of NPD1 as well as of dinor- and tetranormetabolites over time.

These results are of importance since many biologists who do not detect NPD1 in vivo tend to conclude that NPD1 is not formed in vivo. Our results highlight that NPD1 may be metabolized at the time the biological tissues or cells are analysed. Together with the lack of urinary excretion of intact NPD1, these results support the notion of an extremely rapid clearance of NPD1 that may account for variable plasmatic concentrations. The determination of the potential hepatic biotransformation pathway of NPD1 presented here is the first, critical step for the identification of biomarkers that could be used as an index of in vivo production of NPD1.

\section{EXPERIMENTAL SECTION}

General Information: All reactions were performed under an atmosphere of argon unless otherwise specified. Reactions run under argon were conducted in oven-dried glassware $\left(120{ }^{\circ} \mathrm{C}\right.$, minimum 12 hours). Inert gas was dried by passing it through solid anhydrous calcium sulphate (Drierite). Anhydrous diethyl ether, tetrahydrofuran (THF) and dichloromethane were obtained from a PureSolv ${ }^{\mathrm{TM}}$ PS-400 solvent purification system. Acetonitrile, anhydrous toluene and benzene were purchased from Acros or Aldrich. Triethylamine, diisopropylethylamine, pyridine, and hexamethylphosphoramide (HMPA) were freshly distilled over calcium hydride under an argon atmosphere. All commercially available reagents were used without further purification unless otherwise noted. Thin-layer chromatography (TLC) was performed on aluminum pre-coated silica gel plates from Merck, and developed plates were visualized by UV light (254 nm), p-anisaldehyde, or potassium permanganate. Column chromatography was performed using flash chromatography with the indicated eluent on Davisil 40-63 $\mu \mathrm{m}$ silica gel. In some cases, for 
flash column chromatography, deactivated silica (prepared by addition of $46 \mathrm{~mL}$ of water to $100 \mathrm{~g}$ of silica then stirring on rotavapor for $2 \mathrm{~h}$ at $\mathrm{rt}$ without applying vacuum) was used.

${ }^{1} \mathrm{H}$ NMR spectra $(300 \mathrm{MHz}, 500 \mathrm{MHz})$ and ${ }^{13} \mathrm{C}$ NMR spectra $(75 \mathrm{MHz}, 125 \mathrm{MHz})$ were recorded on Bruker AMX300 or Bruker Avance $500 \mathrm{MHz}$ spectrometers respectively. Chemical shifts are reported relative to chloroform $(\delta 7.24 \mathrm{ppm})$ for ${ }^{1} \mathrm{H}$ NMR spectra and chloroform $(\delta 77.16 \mathrm{ppm})$ for $\quad{ }^{13} \mathrm{C}$ NMR spectra. The ${ }^{1} \mathrm{H}$ NMR spectra data are presented as follows: chemical shift, multiplicity $(\mathrm{s}=$ singlet, $\mathrm{d}=$ doublet, $\mathrm{dd}=$ doublet of doublet, $\mathrm{dt}=$ doublet of triplet, $\mathrm{td}=$ triplet of doublet, $\mathrm{t}=$ triplet, $\mathrm{q}=$ quartet, quin = quintet, $\mathrm{m}=$ multiplet, br. = broad), coupling constant(s) in Hertz $(\mathrm{Hz})$, and integration. All the NMR spectra were assigned with the help of 2D NMR techniques (COSY ${ }^{1} \mathrm{H}-{ }^{1} \mathrm{H}, \mathrm{HMQC}$ and $\mathrm{HMBC}$ ).

Infrared spectra were obtained using a Perkin-Elmer Spectrum One spectrophotometer. They were reported as wavenumber $\left(\mathrm{cm}^{-1}\right)$ of significant peaks. Mass spectra (ESI or APCI) and high-resolution mass spectra (HRMS) were measured at the University of Montpellier 2 on either a Waters SYNAPT G2-Si High Definition mass spectrometer or a micromass Q-TOF mass spectrometer. Maldi-Tof spectra were run on a Bruker Ultraflex III spectrometer in a positive reflectron mode. Two matrixes were used: DCTB (trans-2-[3-(4-tert-Butylphenyl)-2-methyl-2- propenylidene]malononitrile) and Ditranol (1,8,9antracenetriol), both enriched with sodium salts (addition of trifluoroacetate). UV-Visible spectra were performed on a Cary 100 spectrophotometer. Purity of all final compounds was $95 \%$ or higher (estimated by HPLC analysis).

\section{HepG2 cell incubations.}

HepG2 cells (a human hepatoma cell line) were cultured in minimal essential medium (MEM) with 10\% FBS and maintained at $37^{\circ} \mathrm{C}$ in humidified atmosphere. At the beginning of the experiments the same number of cells (about 300.000) were plated into $60 \mathrm{~mm}$ cell culture dishes and incubated with medium without FBS. NPD1 $(13,2.6$ or $0.52 \mu \mathrm{M}$, final concentrations), dinor-NPD1 7 (13 $\mu \mathrm{M}$, final 
concentration) or the same volume of ethanol $(0.4 \%)$, were then added to cells for different times of incubation: $30 \mathrm{~min}, 1 \mathrm{~h}, 4 \mathrm{~h}, 8 \mathrm{~h}$ and $24 \mathrm{~h}$. After incubation both the medium and the cells were collected and stored at $-80^{\circ} \mathrm{C}$ for the analyses. An aliquot of the medium was spiked with $d_{4}$-LTB 4 (purchased from Cayman, $10 \mathrm{ng} / \mathrm{sample}$ ), centrifuged and extracted on SPE column as previously published ${ }^{55}$; cell pellets were used for protein determination using the Bradford method.

Direct comparison with $\mathrm{LTE}_{4}$ metabolism by HepG2 was carried out using the same conditions, with 2.6 or $0.52 \mu \mathrm{M}$ final concentrations of both $\mathrm{LTE}_{4}$ and NPD1. An aliquot of the medium collected at 30 min, $1 \mathrm{~h}$ and $4 \mathrm{~h}$ was spiked with $d_{4}-\mathrm{LTB}_{4}$ and $d_{5}-\mathrm{LTE}_{4}$ (purchased from Cayman, $10 \mathrm{ng} / \mathrm{sample}$ ), centrifuged and extracted on SPE column as previously ${ }^{55}$ published. Results were expressed as $\%$ of the amounts measured at T0.

Analysis of HepG2 cell incubations media. RP-HPLC analysis was carried out as previousli5 published with modifications: the column used for separation was an EVO Kinetex C18 (2.1 x $150 \mathrm{~mm}$ x $5 \mu \mathrm{m}$, Phenomenex), eluted at a flow rate of $0.5 \mathrm{~mL} / \mathrm{min}$ with a gradient from $90 \%$ solvent $\mathrm{A}\left(\mathrm{H}_{2} \mathrm{O}+0.05 \mathrm{ml} / \mathrm{L}\right.$ acetic acid, $\mathrm{pH}=5.7)$ to $100 \%$ solvent $\mathrm{B}(65 \%$ acetonitrile $+35 \%$ methanol $)$ over 30 minutes. The effluent from the HPLC was directly interfaced into the electrospray source of a Linear Ion Trap mass spectrometer LTQ (Thermo Fisher), operated in negative ion, and full scans (m/z 100 to 1000) were collected. Extracted ion chromatograms from samples with and without NPD1 were matched and subtracted. Chromatographic peaks associated with NPD1 incubations were further analyzed collecting MS/MS spectra (m/z 100 to 400 in consideration of the parent ion analyzed).

\section{Chemical procedures.}

\section{(5Z,8R,9E,11E,13Z,15S,17Z)-8,15-dihydroxyicosa-5,9,11,13,17-pentaenoic acid (2,3-dinor-NPD1}

7). To a solution of the above-mentioned methyl ester ( $8 \mathrm{mg}, 0.022 \mathrm{mmol})$ in $\mathrm{MeOH}(3 \mathrm{~mL})$ was added 1 $\mathrm{N} \mathrm{LiOH}(1.5 \mathrm{~mL}, 1.5 \mathrm{mmol})$ at $0{ }^{\circ} \mathrm{C}$. The mixture was stirred at $\mathrm{rt}$ for $2.5 \mathrm{~h}$ and diluted with McIlvaine's phosphate buffer $^{57}$ ( $\mathrm{pH}$ 5.0). The resulting mixture was extracted with EtOAc $(2 \times 10 \mathrm{~mL})$. The 
combined extracts were washed with brine $(1 \times 10 \mathrm{~mL})$, dried over $\mathrm{MgSO}_{4}$, filtered through filter paper and concentrated to give the desired 1,2-dinor-NPD1 7 (7.2 mg, 94\%). R f: 0.62 (EtOAc). UV: (EtOH) $\lambda_{\max } 261.8,271.4,282.6 \mathrm{~nm} .{ }^{1} \mathrm{H}$ NMR: $\left(500 \mathrm{MHz}, \mathrm{CD}_{3} \mathrm{OD}\right): \delta 6.51(\mathrm{dd}, J=12.5,13.2 \mathrm{~Hz}, 1 \mathrm{H}), 6.32-$ $6.20(\mathrm{~m}, 2 \mathrm{H}), 6.07(\mathrm{t}, J=11.0 \mathrm{~Hz}, 1 \mathrm{H}), 5.74(\mathrm{dd}, J=6.6,14.6 \mathrm{~Hz}, 1 \mathrm{H}), 5.50-5.41(\mathrm{~m}, 3 \mathrm{H}), 5.40-5.29(\mathrm{~m}$, 2H), $4.56(\mathrm{q}, J=6.2 \mathrm{~Hz}, 1 \mathrm{H}), 4.12(\mathrm{q}, J=6.6 \mathrm{~Hz}, 1 \mathrm{H}), 2.41-2.16(\mathrm{~m}, 6 \mathrm{H}), 2.14-2.00(\mathrm{~m}, 4 \mathrm{H}), 1.65$ (quin, $J=7.4 \mathrm{~Hz}, 2 \mathrm{H}), 1.36-1.25(\mathrm{~m}, 2 \mathrm{H}, \mathrm{OH}), 0.96(\mathrm{t}, J=7.6 \mathrm{~Hz}, 3 \mathrm{H}) \mathrm{ppm} .{ }^{13} \mathrm{C}$ NMR: $\left(125 \mathrm{MHz}, \mathrm{CDCl}_{3}\right): \delta$ $177.8,138.0,135.0,134.8,134.7,132.0,131.4,130.6,128.9,127.1,125.3,73.1,68.6,36.4,36.3,34.6$, 27.8, 26.0, 21.7, 14.9 ppm. MS: (ESI) m/z: $333.21(\mathrm{M}-\mathrm{H}){ }^{+}$.HRMS: (ESI) calculated for $\mathrm{C}_{20} \mathrm{H}_{29} \mathrm{O}_{4}(\mathrm{M}-$ $\mathrm{H})^{+}$333.2066, found 333.2066. MS: (ESI) $\mathrm{m} / \mathrm{z}: 357.20(\mathrm{M}+\mathrm{Na})^{+}$.HRMS: (ESI) calculated for $\mathrm{C}_{20} \mathrm{H}_{30} \mathrm{O}_{4} \mathrm{Na}(\mathrm{M}+\mathrm{Na})^{+}$357.2042, found 357.2045.

(3Z,6R,7E,9E,11Z,13S,15Z)-6,13-dihydroxyoctadeca-3,7,9,11,15-pentaenoic acid 1,2,3,4-tetranorNPD1 (8). To a solution of ester $21(10.0 \mathrm{mg}, 0.0312 \mathrm{mmol})$ in $\mathrm{MeOH}(2 \mathrm{~mL})$ was added $1 \mathrm{~N} \mathrm{LiOH} \mathrm{(1.6}$ $\mathrm{mL}, 1.6 \mathrm{mmol}$ ) at $0{ }^{\circ} \mathrm{C}$. The mixture was stirred at $\mathrm{rt}$ for $1.5 \mathrm{~h}$ and diluted with McIlvaine's phosphate buffer $^{57}(\mathrm{pH}$ 5.0). The resulting mixture was extracted with EtOAc $(2 \times 10 \mathrm{~mL})$. The combined extracts were washed with brine $(1 \times 10 \mathrm{~mL})$, dried over $\mathrm{MgSO}_{4}$, filtered through filter paper and concentrated to give desired 1,2,3,4-tetranor-NPD1 8 (8.43 mg, 88\%). $\mathbf{R}_{\mathbf{f}}: 0.42$ (EtOAc). UV: (EtOH) $\lambda_{\max } 261.2,271.2$, 281.8 nm. ${ }^{1}$ H NMR: $\left(500 \mathrm{MHz}, \mathrm{CD}_{3} \mathrm{OD}\right): \delta 6.52(\mathrm{dd}, J=10.4,13.8 \mathrm{~Hz}, 1 \mathrm{H}), 6.35-6.19(\mathrm{~m}, 2 \mathrm{H}), 6.07$ (t, $J=11.1 \mathrm{~Hz}, 1 \mathrm{H}), 5.76(\mathrm{dd}, J=6.4,14.7 \mathrm{~Hz}, 1 \mathrm{H}), 5.71-5.55(\mathrm{~m}, 2 \mathrm{H}), 5.51-5.41(\mathrm{~m}, 1 \mathrm{H}), 5.40-5.29(\mathrm{~m}$, 2H), $4.56(\mathrm{q}, J=6.3 \mathrm{~Hz}, 1 \mathrm{H}), 4.20-4.12(\mathrm{~m}, 1 \mathrm{H}), 3.08(\mathrm{~d}, J=6.5 \mathrm{~Hz}, 1.67 \mathrm{H}), 3.02(\mathrm{~d}, J=6.5 \mathrm{~Hz}, 0.33 \mathrm{H})$, 2.40-2.24 (m, 4H), 2.23-2.15 (m, 1H), 2.11-2.01 (m, 3H) $0.96(\mathrm{t}, J=7.0 \mathrm{~Hz}, 3 \mathrm{H}) \mathrm{ppm} .{ }^{13} \mathbf{C}$ NMR: $(125$ $\left.\mathrm{MHz}, \mathrm{CDCl}_{3}\right): \delta 177.0,137.8,134.9,134.8,134.7,131.5,130.6,129.4,128.9,125.3,124.9,72.7,68.5$, 41.7, 36.4, 34.0, 21.7, 14.6 ppm. MS: (ESI) m/z: $305.17(\mathrm{M}-\mathrm{H})^{+}$. HRMS: (ESI) calculated for $\mathrm{C}_{18} \mathrm{H}_{25} \mathrm{O}_{4}$ $(\mathrm{M}-\mathrm{H})^{+}$305.1753, found 305.1748.

(3Z,6R,7E,9E,13S,15Z)-methyl 6,13-bis(tert-butyldimethylsilyloxy) octadeca-3,7,9,15-tetraen-11ynoate (Wittig product 15). To a suspension of (2-carboxyethyl)triphenylphosphonium bromide ( 0.53 
$\mathrm{g}, 1.27 \mathrm{mmol}$, prior to use, the phosphonium salt was washed with anhydrous benzene $[3 \mathrm{x} 8 \mathrm{~mL}]$ then dried under vacuum and over $\mathrm{P}_{2} \mathrm{O}_{5}$ for $48 \mathrm{~h}$ at $\left.90{ }^{\circ} \mathrm{C}\right)$ in anhydrous THF $(13 \mathrm{~mL})$ was added NaHMDS (1.0 $\mathrm{mL}, 2.0 \mathrm{mmol}, 2 \mathrm{M}$ solution in Hexane) at $-15^{\circ} \mathrm{C}$. The reaction mixture was stirred for further $30 \mathrm{~min}$ at the same temperature, and then further cooled down to $-78^{\circ} \mathrm{C}$. In another flask, aldehyde $13(0.101 \mathrm{~g}$, $0.21 \mathrm{mmol})$ diluted in THF $(8 \mathrm{~mL})$ was cooled down to $-78^{\circ} \mathrm{C}$. Then the ylide was cannulated to the aldehyde solution under argon. Then temperature was raised to $10^{\circ} \mathrm{C}$ in $2 \mathrm{~h}$. The reaction mixture was quenched with sat. $\mathrm{NH}_{4} \mathrm{Cl}(10 \mathrm{~mL})$ and allowed to warm to rt. After extraction with ethyl ether $(3 \times 30$ $\mathrm{mL})$, the combined organic layers were washed with brine $(1 \times 15 \mathrm{~mL})$, then dried over $\mathrm{NaSO}_{4}$, filtered, and evaporated under reduced pressure. The resulting carboxylic acid crude was used for next step without further purification.

Subsequently, (trimethylsilyl)diazomethane $(0.2 \mathrm{~mL}, 0.396 \mathrm{mmol})$ was added at $0{ }^{\circ} \mathrm{C}$ to a solution of the crude carboxylic acid $(0.115 \mathrm{~g}, 0.21 \mathrm{mmol})$ in ethyl ether/methanol $(9 / 1,3 \mathrm{~mL})$. After stirring at $\mathrm{rt}$ for 45 min, the volatiles were removed under reduced pressure. Purification by flash chromatography (silica, cyclohexane/ethyl ether: 98/02) afforded the expected methyl ester 15 (0.078 g, 69\%) as a colorless oil. The Wittig olefination reaction was not selective, providing a 3Z/3E mixture (ca.70/30 to 85/15, estimated by 1H NMR) $\mathbf{R}_{\mathbf{f}}: 0.81$ (EtOAc/cyclohexane: 2/8). IR (cm-1): 2960, 2933, 2858, 1693, 1473, 1364, 1150, 1162, 973. ${ }^{1} \mathbf{H}$ NMR: (500 MHz, $\mathrm{CDCl}_{3}$ ): $\delta$ [for the (3Z)-isomer] 6.47 (dd, $\left.J=10.9,15.6 \mathrm{~Hz}, 1 \mathrm{H}\right), 6.16$ $(\mathrm{dd}, J=10.9,15.2 \mathrm{~Hz}, 1 \mathrm{H}), 5.72(\mathrm{dd}, J=6.1,15.2 \mathrm{~Hz}, 1 \mathrm{H}), 5.67-5.60(\mathrm{~m}, 1 \mathrm{H}), 5.59-5.45(\mathrm{~m}, 3 \mathrm{H}), 5.42-$ $5.34(\mathrm{~m}, 1 \mathrm{H}), 4.44(\mathrm{td}, J=1.7,6.6 \mathrm{~Hz}, 1 \mathrm{H}), 4.18(\mathrm{q}, J=6.6 \mathrm{~Hz}, 1 \mathrm{H}), 3.65(\mathrm{~s}, 3 \mathrm{H}), 3.05(\mathrm{~d}, J=7.0 \mathrm{~Hz}$ 2H), $2.41(\mathrm{t}, J=7.1 \mathrm{~Hz}, 2 \mathrm{H}), 2.30-2.16(\mathrm{~m}, 2 \mathrm{H}), 2.04$ (quin, $J=7.5 \mathrm{~Hz}, 2 \mathrm{H}), 0.94$ (t, $J=7.5 \mathrm{~Hz}, 3 \mathrm{H}$ ), 0.88 $(\mathrm{s}, 9 \mathrm{H}), 0.86(\mathrm{~s}, 9 \mathrm{H}), 0.10(\mathrm{~s}, 3 \mathrm{H}), 0.08(\mathrm{~s}, 3 \mathrm{H}), 0.01(\mathrm{~s}, 3 \mathrm{H}), 0.00(\mathrm{~s}, 3 \mathrm{H}) \mathrm{ppm}$. 13C NMR: (125 MHz, $\left.\mathrm{CDCl}_{3}\right): \delta$ [for the (3Z)-isomer] $172.4,141.0,138.8,134.4,128.87,126.3,124.0,(2 \mathrm{C}), 124.0,123.1$, $110.9,93.5,83.5,72.4,63.7,52.0,36.8,36.5,33.1,26.0(2 \mathrm{C}), 20.9,18.4,18.3,14.4,-4.4(2 \mathrm{C}),-4.7,-4.8$ ppm. MS: (ESI) m/z: $283.17(\mathrm{M}-2 \mathrm{TBSOH}+\mathrm{H}), 415.27(\mathrm{M}-\mathrm{TBSOH}+\mathrm{H})^{+}, 569.35(\mathrm{M}+\mathrm{Na})^{+}$. HRMS: 
(ESI) calculated for $\mathrm{C}_{19} \mathrm{H}_{23} \mathrm{O}_{2}(\mathrm{M}-2 \mathrm{TBSOH}+\mathrm{H})^{+}$283.1698, found 283.1700. HRMS: (ESI) calculated for $\mathrm{C}_{31} \mathrm{H}_{54} \mathrm{O}_{2} \mathrm{NaSi}_{2}(\mathrm{M}+\mathrm{Na})^{+}$569.3458, found 569.3457.

(6R,7E,9E,13S,15Z)-methyl 3,6,13-trihydroxyoctadeca-7,9,15-trien-11-ynoate (Unexpected triol 16). Tetra-n-butylammonium fluoride $(0.53 \mathrm{~mL}, 0.53 \mathrm{mmol}, 1 \mathrm{M}$ solution in THF $)$ was added to a solution of di-TBS ether $15(72.0 \mathrm{mg}, 0.131 \mathrm{mmol})$ in THF $(4 \mathrm{ml})$ under argon at $0{ }^{\circ} \mathrm{C}$. The cooling bath was removed, and the reaction mixture was stirred for $2 \mathrm{~h}$ at $\mathrm{rt}$. Water $(5 \mathrm{~mL})$ was added. The resulting mixture was extracted with ethyl ether $(2 \times 10 \mathrm{~mL})$. The organic extracts were combined, dried with $\mathrm{MgSO}$, filtered, and concentrated under reduced pressure. The crude residue was purified via column chromatography (silica, cyclohexane/EtOAc, 80/20 to 70/30) to give the triol 16 (25 mg, 50\% yield) as a colorless oil. $\mathbf{R}_{\mathbf{f}}: 0.57$ (EtOAc/cyclohexane: 4/6). IR (cm $\mathbf{~}^{\mathbf{- 1}}$ ): 3428, 3017, 2961, 2926, 2870, 2212, 1736, 1437, 1198, 1048, 985. 1'H NMR: (500 MHz, $\left.\mathrm{CDCl}_{3}\right): \delta 6.51(\mathrm{dd}, J=10.9,15.6 \mathrm{~Hz}, 1 \mathrm{H}), 6.25-6.17(\mathrm{~m}$, 1H), 5.78-5.70 (m, 1H), 5.62-5.54 (m, 2H), 5.44-5.36 (m, 1H), 4.53-4.28 (m, 3H), 3.66 (s, 3H), 2.65-2.58 $(\mathrm{m}, 1 \mathrm{H}), 2.51-2.41(\mathrm{~m}, 3 \mathrm{H}), 2.18-1.97(\mathrm{~m}, 5 \mathrm{H}), 1.73-1.56(\mathrm{~m}, 3 \mathrm{H}), 0.94(\mathrm{t}, J=7.7 \mathrm{~Hz}, 3 \mathrm{H}) \mathrm{ppm} . \quad{ }^{13} \mathrm{C}$ NMR: (125 MHz, $\left.\mathrm{CDCl}_{3}\right): \delta 171.6(\mathrm{C} 1), 141.5(\mathrm{C} 9), 137.0$ and $136.9(\mathrm{C} 7), 136.1(\mathrm{C} 16), 129.9$ and 129.6 (C8), 122.8 (C15), 110.9 and 110.8 (C10), 92.4 (C12), 84.1 (C11), 79.5 and 79.0 (C6), 75.9 and 75.5 (C3), 62.6 (C13), 51.8 (C19), 40.9 and 40.7 (C2), 35.7 (C14), 32.7 and 32.0 (C5), 31.9 and 31.2 (C4), 20.9

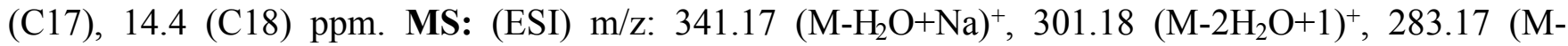
$\left.3 \mathrm{H}_{2} \mathrm{O}+1\right)^{+}$, HRMS: (ESI) calculated for $\mathrm{C}_{19} \mathrm{H}_{26} \mathrm{O}_{4} \mathrm{Na}\left(\mathrm{M}-\mathrm{H}_{2} \mathrm{O}+\mathrm{Na}\right)^{+} 341.1729$, found 341.1727 .

(3Z,6R,7E,9E,13S,15Z)-methyl 6,13-dihydroxyoctadeca-3,7,9,15-tetraen-11-ynoate (Diol 17 via a CSA-silyl deprotection). Catalytic CSA was added to a solution of di-TBS-ether 15 (0.116 g, 0.218 $\mathrm{mmol})$ in $\mathrm{MeOH}(5 \mathrm{~mL})$ at $0{ }^{\circ} \mathrm{C}$. After stirring for $3 \mathrm{~h}$ at $\mathrm{rt}$, the reaction was diluted with water $(10 \mathrm{~mL})$. The aqueous layer was extracted with EtOAc $(2 \times 15 \mathrm{~mL})$. The combined organic phases were washed with brine $\left(1\right.$ x $20 \mathrm{~mL}$ ), dried over $\mathrm{NaSO}_{4}$ and evaporated, and the residue was purified by flash chromatography (silica, cyclohexane/EtOAc: 80/20 to 60/40) to afford diol 17 as a colorless oil (49 mg, 70\%). $\mathbf{R}_{\mathbf{f}}: 0.50$ (EtOAc/cyclohexane: 4/6). 
This procedure provided a 3Z/3E mixture (ca 70/30 to 85/15). The spectral data for yne-ene-diol 17 with a pure (3Z)-olefin are given below with the description of the procedure performed for the TEMPO / BAIB oxidation of primary alcohol $\mathbf{2 0 .}$

(3Z,6R,7E,9E,13S,15Z)-methyl 6,13-dihydroxyoctadeca-3,7,9,15-tetraen-11-ynoate (Diol 17 via a TEMPO/BAIB oxidation). To a stirred solution of primary alcohol $\mathbf{2 0}$ (14 $\mathrm{mg}, 0.027 \mathrm{mmol})$ in $\mathrm{CH}_{2} \mathrm{Cl}_{2} / \mathrm{H}_{2} \mathrm{O}(1 / 1,0.2 \mathrm{~mL}+0.2 \mathrm{~mL})$ were added BAIB $(26 \mathrm{mg}, 0.081 \mathrm{mmol})$ and TEMPO (1.2 mg, 0.0081 mmol) at rt. After stirring at the same temperature for $1 \mathrm{~h}$, the reaction mixture was diluted with $\mathrm{H} \quad{ }_{2} \mathrm{O}$, extracted with $\mathrm{CH}_{2} \mathrm{Cl}_{2}(2 \times 5 \mathrm{~mL})$. The combined organic layers were washed with sat. $\mathrm{Na}_{2} \mathrm{~S}_{2} \mathrm{O}_{3}$ solution (1x $10 \mathrm{~mL})$ and brine $(1 \times 10 \mathrm{~mL})$, dried over $\mathrm{MgSO}_{4}$ then evaporated under reduced pressure. The crude residue was used without further purification for next step.

Catalytic CSA was added to a solution of the above-mentioned carboxylic acid (14 $\mathrm{mg}, 0.027 \mathrm{mmol})$ in $\mathrm{MeOH}(1 \mathrm{~mL})$ at $\mathrm{rt}$. After stirring for $1 \mathrm{~h}$ at $\mathrm{rt}$, the reaction was diluted with sat.NaHCO $3(5 \mathrm{~mL})$. The aqueous layer was extracted with EtOAc $(2 \times 5 \mathrm{~mL})$. The combined organic phases were washed with brine ( $1 \mathrm{x} 10 \mathrm{~mL}$ ), dried over $\mathrm{MgSO}_{4}$ and evaporated, and the residue was purified by flash chromatography (silica, cyclohexane/EtOAc: 80/20 to 60/40) to afford the desired diol 17 as a colorless oil (4.3 mg, 46\%, two steps). $\mathbf{R}_{\mathbf{f}}: 0.50$ (EtOAc/cyclohexane: 4/6). IR (cm $\left.{ }^{-1}\right):$ 3397, 3017, 2961, 2928, 2873, 1736, 1437, 1333, 1167, 988. ${ }^{1} \mathbf{H}$ NMR: (500 MHz, $\left.\mathrm{CDCl}_{3}\right): \delta 6.53(\mathrm{dd}, J=10.9,15.5 \mathrm{~Hz}, 1 \mathrm{H})$, $6.28(\mathrm{dd}, J=10.9,15.1 \mathrm{~Hz}, 1 \mathrm{H}), 5.79(\mathrm{dd}, J=6.0,15.1 \mathrm{~Hz}, 1 \mathrm{H}), 5.74-5.68(\mathrm{~m}, 1 \mathrm{H}), 5.64-5.57(\mathrm{~m}, 3 \mathrm{H})$, 5.44-5.38 (m, 1H), 4.50 (br.t, $J=7.4 \mathrm{~Hz}, 1 \mathrm{H}), 4.24$ (q, $J=6.0 \mathrm{~Hz}, 1 \mathrm{H}), 3.67$ (s, 3H), 3.15-3.03 (m, 2H), 2.52-2.42 (m, 2H), $2.31(\mathrm{t}, J=6.9 \mathrm{~Hz}, 2 \mathrm{H}), 2.16$ (br.s, 1H, OH), 2.10-2.03 (m, 2H), 1.93 (br.s, 1H, OH), $0.96(\mathrm{t}, J=7.6 \mathrm{~Hz}, 3 \mathrm{H})$ ppm. ${ }^{13} \mathrm{C}$ NMR: $\left(125 \mathrm{MHz}, \mathrm{CDCl}_{3}\right): \delta 172.6,141.4,138.0,136.2,129.5,128.4$, 124.6, 122.8, 111.0, 92.5, 84.1, 71.2, 62.7, 52.2, 35.7, 35.5, 32.9, 20.9, 14.4 ppm. MS: (ESI) m/z: 341.17 $(\mathrm{M}+\mathrm{Na})^{+}, 301.18\left(\mathrm{M}-\mathrm{H}_{2} \mathrm{O}+\mathrm{H}\right)^{+}, 283.17\left(\mathrm{M}-2 \mathrm{H}_{2} \mathrm{O}+\mathrm{H}\right)^{+}$.HRMS: (ESI) calculated for $\mathrm{C}_{19} \mathrm{H}_{26} \mathrm{O}_{4} \mathrm{Na}$ $(\mathrm{M}+\mathrm{Na})^{+}$341.1729, found 341.1732. HRMS: (ESI) calculated for ${ }_{9} \mathrm{H}_{25} \mathrm{O}_{3}\left(\mathrm{M}-\mathrm{H}_{2} \mathrm{O}+\mathrm{H}\right)^{+}$301.1804, found 301.1810. HRMS: (ESI) calculated for $\mathrm{C}_{19} \mathrm{H}_{23} \mathrm{O}_{2}\left(\mathrm{M}-2 \mathrm{H}_{2} \mathrm{O}+\mathrm{H}\right)^{+}$283.1696, found 283.1702. 


\section{pyran-2-yloxy)pent-2-enyl)-4,13-dioxa-3,14-disilahexadeca-6,8-dien-10-yne (THP-O-protected (Z)-}

Wittig product 19). To a suspension of triphenyl(3-((tetrahydro-2H-pyran-2-

yl)oxy)propyl)phosphonium bromide $^{5}(0.405 \mathrm{~g}, 0.835 \mathrm{mmol}$, prior to use, the phosphonium salt was washed with anhydrous benzene $\left[3 \times 8 \mathrm{~mL}\right.$ ] then dried under vacuum and over $\mathrm{P}_{2} \mathrm{O}_{5}$ for $48 \mathrm{~h}$ at $80{ }^{\circ} \mathrm{C}$ ) in anhydrous THF $(9 \mathrm{~mL})$ was added NaHMDS $(0.35 \mathrm{~mL}, 0.7 \mathrm{mmol}, 2 \mathrm{M}$ solution in hexane $)$ at $-78^{\circ} \mathrm{C}$. The temperature was raised to $-10^{\circ} \mathrm{C}$. After stirring for further $30 \mathrm{~min}$ at the same temperature, the mixture was cooled down to $-78{ }^{\circ} \mathrm{C}$. The aldehyde $(0.048 \mathrm{~g}, 0.129 \mathrm{mmol})$ was cannulated dropwise to the above prepared ylide. Then, the temperature was raised to $0^{\circ} \mathrm{C}$ in $2 \mathrm{~h}$. The reaction mixture was quenched with sat. $\mathrm{NH}_{4} \mathrm{Cl}(10 \mathrm{~mL})$ and allowed to warm to $\mathrm{rt}$. Upon extraction with ethyl ether $(2 \times 15 \mathrm{~mL})$, the combined organic layers were washed with brine $(1 \times 15 \mathrm{~mL})$, then dried over NaSQ, filtered, and evaporated under reduced pressure. The crude residue was purified via column chromatography (silica, cyclohexane/ethyl ether, 98/02) to provide the desired Wittig product $19(47 \mathrm{mg}, 61 \%$ yield) as a colorless oil. $\mathbf{R} \quad$ f: 0.77 (EtOAc/cyclohexane: 1/9). IR (cm $\left.{ }^{-1}\right):$ 2955, 2929, 2857, 1472, 1254, 1078, 1033, 835. 1 H NMR: (300 $\left.\mathrm{MHz}, \mathrm{CDCl}_{3}\right): \delta 6.48(\mathrm{dd}, J=10.9,15.5 \mathrm{~Hz}, 1 \mathrm{H}), 6.16(\mathrm{dd}, J=10.9,15.2 \mathrm{~Hz}, 1 \mathrm{H}), 5.74(\mathrm{dd}, J=5.9,15.2$ $\mathrm{Hz}, 1 \mathrm{H}), 5.55(\mathrm{dd}, J=1.2,15.6 \mathrm{~Hz}, 1 \mathrm{H}), 5.51-5.31(\mathrm{~m}, 4 \mathrm{H}), 4.57(\mathrm{t}, J=2.8 \mathrm{~Hz}, 1 \mathrm{H}), 4.45(\mathrm{td}, J=1.6,6.5$ $\mathrm{Hz}, 1 \mathrm{H}), 4.43(\mathrm{q}, J=5.9 \mathrm{~Hz}, 1 \mathrm{H}), 3.91-3.79(\mathrm{~m}, 1 \mathrm{H}), 3.76-3.63(\mathrm{~m}, 1 \mathrm{H}), 3.54-3.43(\mathrm{~m}, 1 \mathrm{H}), 3.42-3.32(\mathrm{~m}$, $1 \mathrm{H}), 2.41(\mathrm{t}, J=6.6 \mathrm{~Hz}, 2 \mathrm{H}), 2.37-2.21(\mathrm{~m}, 4 \mathrm{H}), 2.05$ (quin, $J=7.2 \mathrm{~Hz}, 2 \mathrm{H}), 1.89-1.61(\mathrm{~m}, 2 \mathrm{H}), 1.60-$ $1.43(\mathrm{~m}, 4 \mathrm{H}), 0.94(\mathrm{t}, J=7.8 \mathrm{~Hz}, 3 \mathrm{H}), 0.88(\mathrm{~s}, 9 \mathrm{H}), 0.87(\mathrm{~s}, 9 \mathrm{H}), 0.11(\mathrm{~s}, 3 \mathrm{H}), 0.09(\mathrm{~s}, 3 \mathrm{H}), 0.02(\mathrm{~s}, 3 \mathrm{H})$, $0.00(\mathrm{~s}, 3 \mathrm{H}) \mathrm{ppm} .{ }^{13} \mathrm{C}$ NMR: $\left(75 \mathrm{MHz}, \mathrm{CDCl}_{3}\right): \delta 141.2,139.2,134.4,128.7,128.0,127.2,124.1,110.7$, $98.9,93.4,83.6,72.8,67.1,63.7,62.4,36.8,36.5,30.9,28.4,26.0(2 \mathrm{C}), 25.6,20.9,19.7,18.4(2 \mathrm{C}), 14.4$, -4.3 (2C), -4.6, -4.8 ppm. MS: (ESI) m/z: $625.41(\mathrm{M}+\mathrm{Na})^{+}$. HRMS: (ESI) calculated for $\mathrm{C}_{35} \mathrm{H}_{62} \mathrm{O}_{4} \mathrm{NaSi}_{2}$ $(\mathrm{M}+\mathrm{Na})^{+}$625.4084, found 625.4080. 
$\mathrm{MeOH}(3 \mathrm{~mL})$ was added catalytic amount of PPTS at rt. The temperature was raised to $45{ }^{\circ} \mathrm{C}$. After 1.5 $\mathrm{h}$ at $45^{\circ} \mathrm{C}$, monitoring by TLC showed that almost all starting material was consumed. It was diluted with sat. aqueous $\mathrm{NaHCO}_{3}(10 \mathrm{~mL})$, and the resulting aqueous phase was extracted with EtOAc $(2 \times 10 \mathrm{~mL})$. The combined organic layers were washed with brine $(1 \times 10 \mathrm{~mL})$, then dried over $\mathrm{MgSO}_{4}$, filtered, and evaporated under reduced pressure. Purification by chromatography on silica gel (cyclohexane/EtOAc: 95/05) afforded the expected primary alcohol $\mathbf{2 0}(20 \mathrm{mg}, 36 \%)$ as a colorless oil. $\mathbf{R}_{\mathbf{f}}: 0.61$

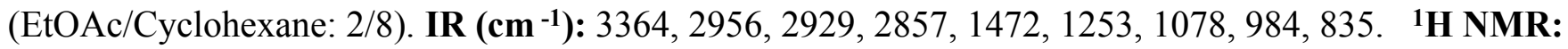
$\left(300 \mathrm{MHz}, \mathrm{CDCl}_{3}\right): \delta 6.48(\mathrm{dd}, J=10.8,15.5 \mathrm{~Hz}, 1 \mathrm{H}), 6.16(\mathrm{dd}, J=10.8,15.2 \mathrm{~Hz}, 1 \mathrm{H}), 5.73(\mathrm{dd}, J=$ $6.1,15.2 \mathrm{~Hz}, 1 \mathrm{H}), 5.60-5.33(\mathrm{~m}, 5 \mathrm{H}), 4.45(\mathrm{td}, J=1.7,6.6 \mathrm{~Hz}, 1 \mathrm{H}), 4.20(\mathrm{q}, J=6.1 \mathrm{~Hz}, 1 \mathrm{H}), 3.61(\mathrm{t}, J=$ $6.3 \mathrm{~Hz}, 2 \mathrm{H}), 2.41(\mathrm{t}, J=6.7 \mathrm{~Hz}, 2 \mathrm{H}), 2.37-2.18(\mathrm{~m}, 4 \mathrm{H}), 2.05$ (quin, $J=7.5 \mathrm{~Hz}, 2 \mathrm{H}), 1.56$ (br.s, 1H, OH), $0.94(\mathrm{t}, J=7.5 \mathrm{~Hz}, 3 \mathrm{H}), 0.88(\mathrm{~s}, 9 \mathrm{H}), 0.87(\mathrm{~s}, 9 \mathrm{H}), 0.11(\mathrm{~s}, 3 \mathrm{H}), 0.09(\mathrm{~s}, 3 \mathrm{H}), 0.02(\mathrm{~s}, 3 \mathrm{H}), 0.00(\mathrm{~s}, 3 \mathrm{H})$ ppm. ${ }^{13} \mathrm{C}$ NMR: $\left(75 \mathrm{MHz}, \mathrm{CDCl}_{3}\right): \delta 141.0,139.0,134.4,128.9,128.8,127.6,124.1,110.9,93.6,83.5$, 72.8, 63.7, 62.3, 36.8, 36.5, 31.2, 26.0 (2C), 20.9, 18.4 (2C), 14.4, -4.3 (2C), -4.6, -4.8 ppm. MS: (ESI) m/z: $255.17(\mathrm{M}-2 \mathrm{TBSOH}+\mathrm{H})^{+}, 387.27(\mathrm{M}-\mathrm{TBSOH}+\mathrm{H})^{+}, 541.35(\mathrm{M}+\mathrm{Na})^{+}$. HRMS: (ESI) calculated for $\mathrm{C}_{30} \mathrm{H}_{54} \mathrm{O}_{3} \mathrm{NaSi}_{2}(\mathrm{M}+\mathrm{Na})^{+}$541.3509, found 541.3506.

The PPTS-catalyzed deprotection conditions were not selective enough. About $30 \mathrm{mg}$ of corresponding triol and diols are collected and reprotected as a tri-TBS ether using TBSCl (75 mg, $0.5 \mathrm{mmol}$ and imidazole (68 mg, $1.0 \mathrm{mmol})$ in $\mathrm{CH}_{2} \mathrm{Cl}_{2}(2 \mathrm{~mL})$ at rt. Subsequently, the resulting tri-TBS ether (40 $\mathrm{mg}$, $0.077 \mathrm{mmol}$ ) was subjected to selective deprotection using PPTS (14 $\mathrm{mg}, 0.077 \mathrm{mmol}$ ), providing the desired primary alcohol 20 in $63 \%$ (20 mg) yield over 2 steps.

\section{(3Z,6R,7E,9E,11Z,13S,15Z)-methyl 6,13-dihydroxyoctadeca-3,7,9,11,15-pentaenoate (E,E,Z-triene}

21). The E,E-ynediene $17(24 \mathrm{mg}, 0.0754 \mathrm{mmol})$ in $\mathrm{MeOH}(5 \mathrm{~mL})$ was added to a suspension of $\mathrm{Zn}(\mathrm{Cu} / \mathrm{Ag})$ mixture $(0.90 \mathrm{~g})$ in water $(5.0 \mathrm{~mL})$. The reaction was stirred at $40^{\circ} \mathrm{C}$ for $1.5 \mathrm{~h}$. Acetonitrile $(15 \mathrm{~mL})$ was added. The reaction mixture was filtered through pad of celite, and washed with EtOAc (20 $\mathrm{mL}$ ), dried over $\mathrm{Na}_{2} \mathrm{SO}_{4}$, and then removal of the solvents afforded a residue that was purified by column 
chromatography (deactivated silica, hexane/EtOAc: 80/20 to 75/25), providing the E,E,Z-triene 21 (10.0 mg, 42\% yield) as a colorless oil. R: 0.40 (EtOAc/cyclohexane: 4/6). IR (cm¹): 3401, 3015, 2960, 2934 , 2875, 1737, 1436, 1331, 1168, 1034, 996. ${ }^{1} \mathbf{H}$ NMR: $\left(500 \mathrm{MHz}, \mathrm{CDCl}_{3}\right): \delta 6.48(\mathrm{dd}, J=11.8,14.5 \mathrm{~Hz}$ $1 \mathrm{H}), 6.34-6.15(\mathrm{~m}, 2 \mathrm{H}), 6.06(\mathrm{t}, J=11.2 \mathrm{~Hz}, 1 \mathrm{H}), 5.79-5.66(\mathrm{~m}, 2 \mathrm{H}), 5.65-5.58(\mathrm{~m}, 1 \mathrm{H})$, 5.57-5.49 (m, $1 \mathrm{H}), 5.43(\mathrm{t}, J=9.7 \mathrm{~Hz}, 1 \mathrm{H}), 5.36-5.27(\mathrm{~m}, 1 \mathrm{H}), 4.57$ (q, $J=7.2 \mathrm{~Hz}, 1 \mathrm{H}), 4.29-4.16(\mathrm{~m}, 1 \mathrm{H}), 3.67(\mathrm{~s}, 3 \mathrm{H})$, 3.14-3.01 (m, 2H), 2.42-2.18 (m, 4H), 2.11 (br.s, 1H, OH), 2.05 (quin, $J=7.0 \mathrm{~Hz}, 2 \mathrm{H}) 1.69$ (br.s, 1H, $\mathrm{OH}), 0.95(\mathrm{t}, J=7.5 \mathrm{~Hz}, 3 \mathrm{H}) \mathrm{ppm} .{ }^{13} \mathrm{C} \mathrm{NMR:}\left(125 \mathrm{MHz}, \mathrm{CDCl}_{3}\right): \delta 172.3,136.4,135.5,133.8,133.7$, $130.5,130.1,128.8,128.0,124.4,123.6,71.5,67.8,52.2,35.6,35.5,33.0,20.9,14.4$ ppm. MS: (ESI) m/z: $343.19(\mathrm{M}+\mathrm{Na})^{+}, 303.20\left(\mathrm{M}-\mathrm{H}_{2} \mathrm{O}+\mathrm{H}\right)^{+}, 285.19\left(\mathrm{M}-2 \mathrm{H}_{2} \mathrm{O}+\mathrm{H}\right)^{+}$. HRMS: (ESI) calculated for $\mathrm{C}_{19} \mathrm{H}_{28} \mathrm{O}_{4} \mathrm{Na}(\mathrm{M}+\mathrm{Na})^{+} 343.1885$, found 343.1881. HRMS: (ESI) calculated for $\mathrm{C}{ }_{19} \mathrm{H}_{27} \mathrm{O}_{3}\left(\mathrm{M}-\mathrm{H}_{2} \mathrm{O}+\mathrm{H}\right)^{+}$ 303.1960, found 303.1957. HRMS: (ESI) calculated for $\mathrm{C}_{19} \mathrm{H}_{25} \mathrm{O}_{2}\left(\mathrm{M}-2 \mathrm{H}_{2} \mathrm{O}+\mathrm{H}\right)^{+}$285.1855, found 285.1855 .

\section{Other compounds}

The syntheses of NPD1 and dinor-NPD1 7 have been performed according to our previouslis, 40 reported synthesis of protectin isomers, using slighly modified procedures. Thus, the procedures for the chemical synthesis of all the precursors and targets discussed in the present manuscript, their characterization (NMR, MS, IR, UV) and their NMR spectra have been collected in the supporting information file.

\section{Quantitative determination of NPD1, dinor-NPD1 (7), and tetranor-NPD1 (8).}

Quantitative determinations of NPD1, dinor-NPD1 (7), and tetranor-NPD1 (8), were carried out by RP/HPLC and multiple reaction monitoring (MRM)-mass spectrometry using the same column and solvents but shortening the gradient (\%B from 65 to 100 in 6 minutes). The effluent from the HPLC was 
directly interfaced into the electrospray source of a triple quadrupole (ABSciex API 4000) operated in negative ion mode. For each compound 2 different fragments arising from the molecular ion (M-H) were


dihydroxylated, conjugated triene derived from arachidonic acid instead of DHA, was used as internal standard, monitoring the abundant fragmentation observed at the transition $\mathrm{m} / \mathrm{z} 339$ to 197 as a quantifier. With an RP-HPLC retention time very close to NPD1, $d_{4}-\mathrm{LTB}_{4}$ represents an excellent internal standard, sharing with NPD1 a conjugated triene system flanked by two hydroxyl groups. Furthermore, being a stable isotope analog, $d_{4}-\mathrm{LTB}_{4}$ is clearly devoid of potential interferences from the corresponding endogenous compound.

Standard curves obtained always showed a correlation coefficient $r>0.99$ (Supporting Figure S2); accuracy averaged $98.8 \%$ throughout the different levels of the standard curve, and repeated analysis showed a CV of $7.3 \%$ at $1 \mathrm{ng} / \mathrm{ml}$ of NPD1 and a limit of quantitation of $0.1 \mathrm{ng} / \mathrm{ml},(\mathrm{S} / \mathrm{N}>10)$.

\section{Human urine analysis.}

First morning urines were collected from 6 de-identified healthy donors ( 3 males and 3 females; $36.6 \pm 8.9$ yo), that had not taken NSAIDs over the last 7 days; $1 \mathrm{~mL}$ aliquots were added with BHT $(5 \mu \mathrm{g} / \mathrm{mL}$, final concentration) and $5 \mathrm{ng}$ of $q \mathrm{LTB}_{4}$ as internal standard, and stored at $-30^{\circ} \mathrm{C}$ until analysis. Separate samples were spiked with synthetic NPD1 (50 ng) and maintained at room temperature for up to $24 \mathrm{~h}$, either in presence or absence of BHT, before adding internal standard and storage at $-30^{\circ} \mathrm{C}$. Upon thawing, samples were extracted on Strata-X (Phenomenex, Torrance, CA) solid phase cartridges and analysis of NPD1, dinor-NPD1 and tetranor-NPD1 was carried out by LC/MS/MS as described above. 


\section{PMN Isolation and $\mathrm{LTB}_{4}$-induced Chemotaxis.}

Peripheral blood human PMN were purified as previously described. ${ }^{59}$ In brief, PMNL were isolated by density centrifugation over Percoll $(d=1.077)$ from whole blood obtained from de-identified healthy donors that had not taken NSAIDs over the last 7 days. Red blood cells were lysed by hypotonic lysis. Chemotaxis experiments were performed in a 48-well modified microchemotaxis chamber (Neuro Probe, Gaithersburg, MD, USA) using $5 \mu \mathrm{m}$ nucleoporepolyvinylpyrrolidine-free polycarbonate filters.

Lower chambers were filled with RPMI supplemented with $0.1 \%$ bovine serum albumin (BSA) and $\mathrm{LTB}_{4}(10 \mathrm{nM})$ as chemotactic stimulus. Negative controls were performed using the solvent of LTB 4 (EtOH). Upper chambers were filled with $50 \mu \mathrm{L}$ cell suspension $(2 \times 10$ cells $/ \mathrm{mL}$ in RPMI 1640 with $0.1 \%$ BSA); NPD1, dinor-NPD1 or tetranor-NPD1 $(0.01-10 \mathrm{nM})$ or their solvent (EtOH) were added both in the upper and lower compartment. After 90 min incubation at $37^{\circ} \mathrm{C}$ non-migrating cells on the upper filter surface were removed by scraping. The cells migrated to the lower side of the filter were stained with Diff-Quick stain (VWR Scientific Products, Bridgeport, NJ, USA), and densitometric analysis was performed using the Image J 1,47v software (NIH, USA). Each experiment was performed in sextuplicate and repeated with PMNL from 3-4 different donors.

\section{In vivo activity in acute pulmonary inflammation and FACS analysis.}

Female FVB (7-8 week old) mice were purchased from Harlan Laboratories Italy (S. Pietro al Natisone, Udine, Italy). Animals were maintained under conventional housing conditions. Prior to use, animals were acclimated for at least 5 days to the local vivarium conditions (room temperature: $20-24^{\circ} \mathrm{C}$; relative humidity: 40-70\%), having free access to standard rat chow and tap water. All animal experiments were carried out in agreement with the revised "Guide for the Care and Use of Laboratory Animals ${ }^{\natural 0}$ and were approved by the Institutional Animal Care and Use Committee at Chiesi Farmaceutici. Intratracheal (i.tr.) 
challenge with LPS was carried out using $50 \mu \mathrm{L}$ of LPS solution $(250 \mu \mathrm{g} / \mathrm{mL}$ in phosphate buffered solution $[\mathrm{PBS}])$ containing $10 \mathrm{ng}$ of tetranor-NPD1 or its solvent (EtOH, 2\% final). Control animals received $50 \mu \mathrm{L}$ of PBS with 2\% EtOH. BAL collection was performed 24 hours after LPS challenge. Mice were sacrificed by an overdose of isoflurane and a midline neck incision was performed to cannulate the trachea. Lungs were washed three times with $0.6 \mathrm{ml}$ of PBS as previously ${ }^{61}$ described. Cells were isolated by centrifugation and stained with the proper amounts of antibodies. The antibody panel was designed as follows: CD45 PE-Cy5 (BD) to first positively select all leucocytes and gate out debris, F4/80 Alexa488 (eBioscience) to gate out macrophages, Lys6G-PE (BD) and CD11b PE-Cy7 to positively identify neutrophils. BD Truecount ${ }^{\mathrm{TM}}$ Tubes were used to determine the absolute number of neutrophils in BAL. Acquisition and analysis was performed on a FACS Canto II (Becton Dickinson) using Diva 7.0 software.

\section{ASSOCIATED CONTENT}

*Supporting Information

This material is available free of charge via the Internet at http://pubs.acs.org and shows:

- Chemical procedures for the synthesis of targets 7, 8 and NPD1 and all their precursors

- ${ }^{1} \mathrm{H}$ and ${ }^{13} \mathrm{C}$ NMR spectra

- Purity: HPLC chromatograms for NPD1 and its metabolites 7 and 8

- Figure S1. MS/MS fragmentation spectrum of the negative ion at m/z 375 - assigned to compound 22-OH-NPD1

- Figure S2. LC-MS/MS with selected reaction monitoring of HepG2 cell medium for NPD1, dinor-NPD1 7, and tetranor-NPD1 8

- $\quad$ Figure S3. Calibration curves of NPD1, dinor-NPD1 (7), and tetranor-NPD1 (8) obtained using $\boldsymbol{d}_{4}-\mathbf{L T B}_{4}$ as internal standard

- $\quad$ SMILES molecular strings formulas (CSV) 


\section{AUTHOR INFORMATION}

\section{Corresponding Author}

*E-mail: laurence.balas@umontpellier.fr ; Phone: +33 (0) 411759529

E-mail: angelo.sala@unimi.it ; Phone: +39 0250318308

\section{Author Contributions}

LB, TD, AS designed the experiments, carried out the critical analysis of results, drafted and approved the manuscript; GD, LB carried out the chemical syntheses; PR, CB carried out the cell culture experiments and the mass spectrometric analysis; FS carried out the in vivo experiments in mice; AT and CB carried out the $\mathrm{LTB}_{4}$-induced chemotaxis assays; GR performed data analysis; GD, PR, CB, AT, FS, GR, CB contributed to, and approved the manuscript.

\section{Notes}

The authors declare no competing financial interest.

\section{ACKNOWLEDGMENTS}

We thank Mr. Flavio Giavarini and Dr. Roberto Spezzano for technical assistance with linear ion trap analysis. DG thanks the University of Montpellier for the postdoctoral fellowship. The study was supported by institutional research funds at the University of Milano, University of Padova and CNRS.

\section{ABBREVIATIONS USED}

APCI, atmospheric pressure chemical ionization; AT, aspirin-triggered; BAIB, bis(acetoxyiodo)benzene; BAL, Bronchoalveolar lavage; BHT, 2,6-Di-tert-butyl-4-methylphenol; BOR, Bestmann Ohira reaction; br s, broad signal; n-BuLi, n-butyllithium; cat., catalytic; CoA, co-enzyme A; CSA, camphorsulfonic acid; $\mathrm{d}_{4}$-LTB 4 , 5(S),12(R)-dihydroxy-6Z,8E,10E,14Z-eicosatetraenoic acid; EPA, eicosapentaenoic acid; FBS, fetal bovine serum; FVB, Friend Virus B-Type; Imid., imidazole; LPS, lipopolysaccharide; LTE 4 leukotriene E4 - 5S-hydroxy-6R-(S-cysteinyl)-7E,9E,11Z,14Z-eicosatetraenoic acid; NaHMDS, 
sodium bis(trimethylsilyl)amide; n-BuLi, n-butyllithium; [Ox.], oxidation; PMN, polymorphonuclear neutrophils; PMNL, polymorphonuclear leukocyte; PPTS, p-toluenesulfonic acid pyridine salt; Quant., quantitative; RP/HPLC, reverse phase high pressure liquid chromatography; RPMI, Roswell Park Memorial Institute medium; rt, room temperature; sat., saturated; SPM, Specialized Pro-resolving Mediators; TBDPS, tributyldiphenylsilyl; TEMPO, 2,2,6,6-tetramethyl-1-piperidinyloxy free radical; TES, triethylsilyl.

\section{References}

1. Hong, S.; Gronert, K.; Devchand, P. R.; Moussignac, R. L.; Serhan, C. N., Novel docosatrienes and 17S-resolvins generated from docosahexaenoic acid in murine brain, human blood, and glial cells. Autacoids in anti-inflammation. J. Biol. Chem. 2003, 278 (17), 14677-14687.

2. Mukherjee, P. K.; Marcheselli, V. L.; Serhan, C. N.; Bazan, N. G., Neuroprotectin D1: a docosahexaenoic acid-derived docosatriene protects human retinal pigment epithelial cells from oxidative stress. Proc. Natl. Acad. Sci. U. S. A. 2004, 101 (22), 8491-8496.

3. Serhan, C. N.; Gotlinger, K.; Hong, S.; Lu, Y.; Siegelman, J.; Baer, T.; Yang, R.; Colgan, S. P.; Petasis, N. A., Anti-inflammatory actions of neuroprotectin D1/protectin D1 and its natural stereoisomers: assignments of dihydroxy-containing docosatrienes. J. Immunol. 2006, 176 (3), 1848 1859.

4. Serhan, C. N.; Petasis, N. A., Resolvins and protectins in inflammation resolution. Chem. Rev. 2011, $111(10), 5922-5943$.

5. Serhan, C. N.; Dalli, J.; Colas, R. A.; Winkler, J. W.; Chiang, N., Protectins and maresins: New pro-resolving families of mediators in acute inflammation and resolution bioactive metabolome. Biochim. Biophys. Acta 2015, 1851 (4), 397-413.

6. Balas, L.; Guichardant, M.; Durand, T.; Lagarde, M., Confusion between protectin D1 (PD1) and its isomer protectin DX (PDX). An overview on the dihydroxy-docosatrienes described to date. Biochimie 2014, $99,1-7$. 
7. Balas, L.; Durand, T., Dihydroxylated E,E,Z-docosatrienes. An overview of their synthesis and biological significance. Prog. Lipid Res. 2016, 61, 1-18.

8. Serhan, C. N., Pro-resolving lipid mediators are leads for resolution physiology. Nature 2014, 510 (7503), 92-101.

9. Morita, M.; Kuba, K.; Ichikawa, A.; Nakayama, M.; Katahira, J.; Iwamoto, R.; Watanebe, T.; Sakabe, S.; Daidoji, T.; Nakamura, S.; Kadowaki, A.; Ohto, T.; Nakanishi, H.; Taguchi, R.; Nakaya, T.; Murakami, M.; Yoneda, Y.; Arai, H.; Kawaoka, Y.; Penninger, J. M.; Arita, M.; Imai, Y., The lipid mediator protectin D1 inhibits influenza virus replication and improves severe influenza. Cell 2013, $153(1), 112-125$.

10. Serhan, C. N.; de la Rosa, X.; Jouvene, C., Novel mediators and mechanisms in the resolution of infectious inflammation: evidence for vagus regulation. J. Intern. Med. 2019, 286 (3), 240-258.

11. Barden, A.; Mas, E.; Croft, K. D.; Phillips, M.; Mori, T. A., Short-term n-3 fatty acid supplementation but not aspirin increases plasma proresolving mediators of inflammation. J. Lipid Res. 2014, 55 (11), 2401-2407.

12. Colas, R. A.; Shinohara, M.; Dalli, J.; Chiang, N.; Serhan, C. N., Identification and signature profiles for pro-resolving and inflammatory lipid mediators in human tissue. Am. J. Physiol. Cell Physiol. 2014, 307 (Lm), C39-C54.

13. Grenon, S. M.; Owens, C. D.; Nosova, E. V.; Hughes-Fulford, M.; Alley, H. F.; Chong, K.; Perez, S.; Yen, P. K.; Boscardin, J.; Hellmann, J.; Spite, M.; Conte, M. S., Short-term, high-dose fish oil supplementation increases the production of $\omega-3$ Fatty acid-derived mediators in patients with peripheral artery disease (the OMEGA-PAD I Trial). J. Am. Heart Assoc. 2015, 4 (8), e002034-e002034. 14. Barden, A. E.; Mas, E.; Croft, K. D.; Phillips, M.; Mori, T. A., Specialized proresolving lipid mediators in humans with the metabolic syndrome after n-3 fatty acids and aspirin. Am. J. Clin. Nutr. 2015, $102(6), 1357-1364$. 
1 5. Mas, E.; Barden, A.; Burke, V.; Beilin, L. J.; Watts, G. F.; Huang, R. C.; Puddey, I. B.; Irish, A. B.; Mori, T. A., A randomized controlled trial of the effects of n-3 fatty acids on resolvins in chronic kidney disease. Clin. Chem. 2016, 35 (2), 331-336.

16. Frediani, J. K.; Jones, D. P.; Tukvadze, N.; Uppal, K.; Sanikidze, E.; Kipiani, M.; Tran, V. T.; Hebbar, G.; Walker, D. I.; Kempker, R. R.; Kurani, S. S.; Colas, R. A.; Dalli, J.; Tangpricha, V.; Serhan, C. N.; Blumberg, H. M.; Ziegler, T. R., Plasma metabolomics in human pulmonary tuberculosis disease: A pilot study. PLOS ONE 2014, 9 (10), e108854-e108854.

1 7. Skarke, C.; Alamuddin, N.; Lawson, J. A.; Li, X.; Ferguson, J. F.; Reilly, M. P.; FitzGerald, G. A., Bioactive products formed in humans from fish oils. J. Lipid Res. 2015, 56 (9), 1808-1820.

1 8. Mas, E.; Croft, K. D.; Zahra, P.; Barden, A.; Mori, T. A., Resolvins D1, D2, and other mediators of self-limited resolution of inflammation in human blood following n-3 fatty acid supplementation. Clin. Chem. 2012, $58(10), 1476-1484$.

19. Sasaki, A.; Fukuda, H.; Shiida, N.; Tanaka, N.; Furugen, A.; Ogura, J.; Shuto, S.; Mano, N.; Yamaguchi, H., Determination of omega-6 and omega-3 PUFA metabolites in human urine samples using UPLC/MS/MS. Anal. Bioanal. Chem. 2015, 407 (6), 1625-1639.

20 . Norris, P. C.; Skulas-Ray, A. C.; Riley, I.; Richter, C. K.; Kris-Etherton, P. M.; Jensen, G. L.; Serhan, C. N.; Maddipati, K. R., Identification of specialized pro-resolving mediator clusters from healthy adults after intravenous low-dose endotoxin and omega-3 supplementation: a methodological validation. Sci. Rep. 2018, 8 (1), 18050-18063 - doi: 10.1038/s41598-018-36679-4.

2 1. Elajami, T. K.; Colas, R. A.; Dalli, J.; Chiang, N.; Serhan, C. N.; Welty, F. K., Specialized proresolving lipid mediators in patients with coronary artery disease and their potential for clot remodeling. FASEB J. 2016, 30 (8), 2792-2801.

2 2. Mozurkewich, E. L.; Greenwood, M.; Clinton, C.; Berman, D.; Romero, V.; Djuric, Z.; Qualls, C.; Gronert, K., Pathway markers for pro-resolving lipid mediators in maternal and umbilical cord blood: A secondary analysis of the mothers, omega-3, and mental health study. Front. Pharmacol. 2016, 7, 1-7 - DOI: 10.3389/fphar.2016.00274 
23. Tungen, J. E.; Aursnes, M.; Vik, A.; Ramon, S.; Colas, R. A.; Dalli, J.; Serhan, C. N.; Hansen, T. V., Synthesis and anti-inflammatory and pro-resolving activities of 22-OH-PD1, a monohydroxylated metabolite of protectin D1. J. Nat. Prod. 2014, 77 (10), 2241-2247.

24. Shirley, M. A.; Murphy, R. C., Metabolism of leukotriene B4 in isolated rat hepatocytes. Involvement of 2,4-dienoyl-coenzyme A reductase in leukotriene B4 metabolism. J. Biol. Chem. 1990, 265 (27), 16288-16295.

25. Jedlitschky, G.; Huber, M.; Volkl, A.; Muller, M.; Leier, I.; Muller, J.; Lehmann, W. D.; Fahimi, H. D.; Keppler, D., Peroxisomal degradation of leukotrienes by beta-oxidation from the omegaend. J. Biol. Chem. 1991, 266 (36), 24763-247672.

26. Mayatepek, E.; Lehmann, W. D.; Fauler, J.; Tsikas, D.; Frolich, J. C.; Schutgens, R. B.; Wanders, R. J.; Keppler, D., Impaired degradation of leukotrienes in patients with peroxisome deficiency disorders. J. Clin. Invest. 1993, 91 (3), 881-888.

27. Hong, S.; Porter, T. F.; Lu, Y.; Oh, S. F.; Pillai, P. S.; Serhan, C. N., Resolvin E1 metabolome in local inactivation during inflammation-resolution. J. Immunol. 2008, 180 (5), 3512-3519.

28. Arita, M.; Oh, S. F.; Chonan, T.; Hong, S.; Elangovan, S.; Sun, Y.-P. P.; Uddin, J.; Petasis, N. A.; Serhan, C. N., Metabolic inactivation of resolvin E1 and stabilization of its anti-inflammatory actions. J. Biol. Chem. 2006, 281 (32), 22847-22854.

29. Colas, R. A.; Dalli, J.; Chiang, N.; Vlasakov, I.; Sanger, J. M.; Riley, I. R.; Serhan, C. N., Identification and actions of the maresin 1 metabolome in infectious inflammation. J. Immunol. 2016, 197 (11), 4444-4452.

30. Clish, C. B.; Levy, B. D.; Chiang, N.; Tai, H.-H.; Serhan, C. N., Oxidoreductases in lipoxin $\mathrm{A}_{4}$ metabolic inactivation. J. Biol. Chem. 2000, 275 (33), 25372-25380.

31. Huber, M.; Müller, J.; Leier, I.; Jedlitschky, G.; Ball, H. A.; Moore, K. P.; Taylor, G. W.; Williams, R.; Keppler, D., Metabolism of cysteinyl leukotrienes in monkey and man. Eur. J. Biochem. 1990, 194, 309-315. 
32. Sala, A.; Voelkel, N. F.; Maclouf, J.; Murphy, R. C., Leukotriene Eelimination in normal human subjects. J. Biol. Chem. 1990, 265 (35), 21771-21778.

33. Murphy, R. C.; Stene, D. O., Oxidative metabolism of leukotriene $\mathrm{E}_{4}$ by rat Hepatocytes. Ann. N. Y. Acad. Sci. 1988, 35-43.

34. Lawson, J. A.; Kim, S.; Powell, W. S.; FitzGerald, G. A.; Rokach, J., Oxidized derivatives of omega-3 fatty acids: identification of IPF ${ }_{3}$ alpha-VI in human urine. J. Lipid Res. 2006, 47 (11), 25152524.

35. Clish, C. B.; O'Brien, J. A.; Gronert, K.; Stahl, G. L.; Petasis, N. A.; Serhan, C. N., Local and systemic delivery of a stable aspirin-triggered lipoxin prevents neutrophil recruitment in vivo. Proc. Natl. Acad. Sci. U. S. A. 1999, 96 (14), 8247-8252.

36. Dayaker, G.; Durand, T.; Balas, L., A versatile and stereocontrolled total synthesis of dihydroxylated docosatrienes containing a conjugated E,E,Z-triene. Chem. Eur. J. 2014, 20 (10), 28792887.

37. Ahmed, R.; Altieri, A.; Dsouza, D. M.; Leigh, D. A.; Mullen, K. M.; Papmeyer, M.; Slawin, A. M. Z.; Wong, J. K. Y.; Woollins, J. D., Phosphorus-based functional groups as hydrogen bonding templates for rotaxane formation. J. Am. Chem. Soc. 2011, 133 (31), 12304-12310.

38. Sharma, G. V. M.; Reddy, P. S., Total synthesis of macrosphelide M from diacetone glucose. Eur. J. Org. Chem. 2012, 2414-2421.

39. Rodriguez, A. R.; Spur, B. W., Total synthesis of aspirin-triggered 15-epi-lipoxin A. Tetrahedron Lett. 2001, (42), 6057-6060.

40. Dayaker, G.; Durand, T.; Balas, L., Total synthesis of neuroprotectin D1 analogues derived from omega-6 docosapentaenoic acid (DPA) and adrenic acid (AdA) from a common pivotal, late-stage intermediate. J. Org. Chem. 2014, 79 (6), 2657-2665.

41. Halapin, N. A.; Bazan, N. G., NPD1 induction of retinal pigment epithelial cell survival involves PI3K/Akt phosphorylation signaling. Neurochem. Res. 2010, 35 (12), 1944-1947. 
42. Marcheselli, V. L.; Hong, S.; Lukiw, W. J.; Tian, X. H.; Gronert, K.; Musto, A.; Hardy, M.; Gimenez, J. M.; Chiang, N.; Serhan, C. N.; Bazan, N. G., Novel docosanoids inhibit brain ischemiareperfusion-mediated leukocyte infiltration and pro-inflammatory gene expression. J. Biol. Chem. 2003, $278(44), 43807-43817$.

43. Bang, S.; Xie, Y.-K.; Zhang, Z.-J.; Wang, Z.; Xu, Z.-Z.; Ji, R.-R., GPR37 regulates macrophage phagocytosis and resolution of inflammatory pain. J. Clin. Invest. 2018, 128 (8), 3568-3582.

44. Chiang, N.; Serhan, C. N., Cell-cell interaction in the transcellular biosynthesis of novel $\omega-3-$ derived lipid mediators. Meth. Mol. Biol. 2006, 341, 227-250.

45. Wanders, R. J. A.; Waterham, H. R.; Ferdinandusse, S., Metabolic interplay between peroxisomes and other subcellular organelles ncluding mitochondria and the endoplasmic reticulum. Front. Cell Dev. Biol. 2016, 3, Article 83 - doi: 10.3389/fcell.2015.00083.

46. Hunt, M. C.; Tillander, V.; Alexson, S. E. H., Regulation of peroxisomal lipid metabolism: The role of acyl-CoA and coenzyme A metabolizing enzymes. Biochimie 2014, 98 (98), 45-55.

47. Kølvraa, S.; Gregersen, N., In vitro studies on the oxidation of medium-chain dicarboxylic acids in rat liver. Biochim. Biophys. Acta 1986, 876 (3), 515-525.

48. Stene, D. O.; Murphy, R. C., Metabolism of leukotriene E ${ }_{4}$ in isolated rat hepatocytes. J. Biol. Chem. 1988, 263 (6), 2773-2778.

49. Murphy, R. C.; Sala, A.; Voelkel, N.; Maclouf, J., Appearance of urinary metabolites of LTE 4 in human subjects. Ann. N. Y. Acad. Sci. 1991, 629, 105-111.

50. You, S. Y.; Cosloy, S.; Schulz, H., Evidence for the essential function of 2,4-dienoyl-coenzyme A reductase in the $\beta$-oxidation of unsaturated fatty acids in vivo. Isolation and characterization of an Escherichia coli mutant with a defective 2,4-dienoyl-coenzyme A reductase. J. Biol. Chem. 1989, 264 (28), 16489-164895.

51. Li, H.; Lawson, J. A.; Reilly, M.; Adiyaman, M.; Hwang, S.-W.; Rokach, J.; FitzGerald, G. A., Quantitative high performance liquid chromatography/tandem mass spectrometric analysis of the four classes of F2-isoprostanes in human urine. Proc. Natl. Acad. Sci. U. S. A. 1999, 96 (23), 13381-13386. 
52. Catella, F.; Nowak, J.; Fitzgerald, G. A., Measurement of renal and non-renal eicosanoid synthesis. Am. J. Med. 1986, 81 (2 SUPPL. 2), 23-29.

53. Rabinovitch, N., Urinary leukotriene E4. Immunol. Allergy Clin. North Am. 2007, 27, 651-664.

54. Sala, A.; Armetti, L.; Folco, G.; Piva, A., An improved assay for urinary LTE ${ }_{4}$. Prostaglandins 1994, 47 (4), 281-292.

55. Sala, A.; Bolla, M.; Zarini, S.; Muller-Peddinghaus, R.; Folco, G.; Müller-Peddinghaus, R.; Folco, G., Release of leukotriene $\mathrm{A}_{4}$ versus leukotriene $\mathrm{B}_{4}$ from human polymorphonuclear leukocytes. $J$. Biol. Chem. 1996, 271 (30), 17944-17948.

56. Zarini, S.; Gijon, M. A.; Ransome, A. E.; Murphy, R. C.; Sala, A.; Gijón, M. A.; Ransome, A. E.; Murphy, R. C.; Sala, A., Transcellular biosynthesis of cysteinyl leukotrienes in vivo during mouse peritoneal inflammation. Proc. Natl. Acad. Sci. U. S. A 2009, 106 (20), 8296-8301.

57. McIlvaine, T. C., A buffer solution for colorimetric comparison. J. Biol. Chem. 1921, 49, 183-186. 58. G. H. Jimenez-Aleman; R. A. R. Machado; H. Görls; Baldwin, I. T.; Boland, W., Synthesis, structural characterization and biological activity of two diastereomeric JA-Ile macrolactones. Org. Biomol. Chem. 2015, 5885-5893.

59. Sala, A.; Zarini, S.; Folco, G.; Murphy, R. C.; Henson, P. M., Differential metabolism of exogenous and endogenous arachidonic acid in human neutrophils. J. Biol. Chem. 1999, 274 (40), 2826428269.

60. Guide for the Care and Use of Laboratory Animals. National Academy Press: Washington, D.C., 1996.

61. Nassini, R.; Pedretti, P.; Moretto, N.; Fusi, C.; Carnini, C.; Facchinetti, F.; Viscomi, A. R.; Pisano, A. R.; Stokesberry, S.; Brunmark, C.; Svitacheva, N.; McGarvey, L.; Patacchini, R.; Damholt, A. B.; Geppetti, P.; Materazzi, S., Transient receptor potential ankyrin 1 channel localized to nonneuronal airway cells promotes non-neurogenic inflammation. PLOS ONE 2012, 7 (8), e42454-e42454. 
SYNOPSIS (Word Style "SN_Synopsis_TOC").

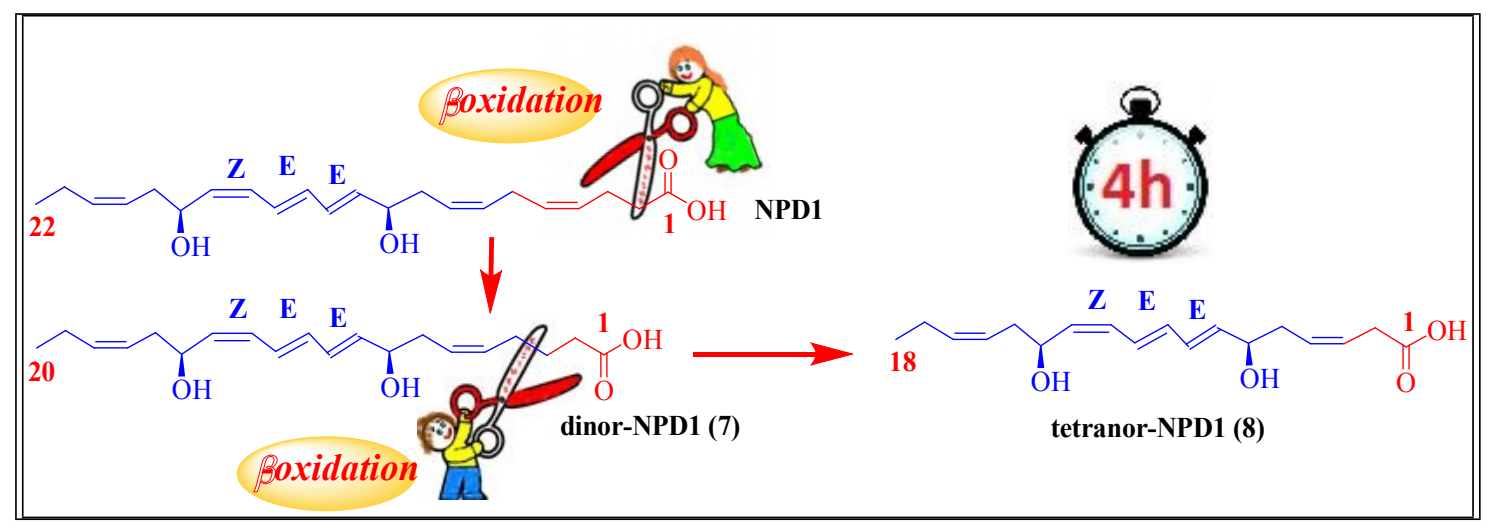

